\title{
Impact of climate change on biodiversity and food security: a global perspective-a review article
}

\author{
Melese Genete Muluneh ${ }^{*}$ (D)
}

\begin{abstract}
Climate change is happening due to natural factors and human activities. It expressively alters biodiversity, agricultural production, and food security. Mainly, narrowly adapted and endemic species are under extinction. Accordingly, concerns over species extinction are warranted as it provides food for all life forms and primary health care for more than $60-80 \%$ of humans globally. Nevertheless, the impact of climate change on biodiversity and food security has been recognized, little is explored compared to the magnitude of the problem globally. Therefore, the objectives of this review are to identify, appraise, and synthesize the link between climate change, biodiversity, and food security. Data, climatic models, emission, migration, and extinction scenarios, and outputs from previous publications were used. Due to climate change, distributions of species have shifted to higher elevations at a median rate of $11.0 \mathrm{~m}$ and $16.9 \mathrm{~km}$ per decade to higher latitudes. Accordingly, extinction rates of 1103 species under migration scenarios, provide $21-23 \%$ with unlimited migration and $38-52 \%$ with no migration. When an environmental variation occurs on a timescale shorter than the life of the plant any response could be in terms of a plastic phenotype. However, phenotypic plasticity could buffer species against the long-term effects of climate change. Furthermore, climate change affects food security particularly in communities and locations that depend on rain-fed agriculture. Crops and plants have thresholds beyond which growth and yield are compromised. Accordingly, agricultural yields in Africa alone could be decline by more than $30 \%$ in 2050 . Therefore, solving food shortages through bringing extra land into agriculture and exploiting new fish stocks is a costly solution, when protecting biodiversity is given priority. Therefore, mitigating food waste, compensating food-insecure people conserving biodiversity, effective use of genetic resources, and traditional ecological knowledge could decrease further biodiversity loss, and meet food security under climate change scenarios. However, achieving food security under such scenario requires strong policies, releasing high-yielding stress resistant varieties, developing climate resilient irrigation structures, and agriculture. Therefore, degraded land restoration, land use changes, use of bio-energy, sustainable forest management, and community based biodiversity conservation are recommended to mitigate climate change impacts.
\end{abstract}

Keywords: Adaptation, Conservation, Ecosystems, Extinction, Greenhouse gases, Habitat fragmentation, Precipitation, Species range shifts, Global warming, Wild relatives

*Correspondence: melese.genete@wu.edu.et; melesegenete2011@gmail.com Department of Forestry, College of Agriculture, Wollo University, P.O. Box 1145, Dessie, Ethiopia

\section{Introduction}

Climate is defined as the average weather conditions, characterized by long-term statistics for the meteorological elements in a given area [1]. While climate change $(\mathrm{CC})$ is described as the change in the climate of an area as a result of anthropogenic and natural disorders such as 
the depletion of the ozone layer, and greenhouse effects [2]. It may result from factors such as changes in solar emission, long-term changes in the earth's orbital elements (eccentricity, obliquity of the ecliptic, the procession of the equinoxes), natural processes, and human forcing on a planet. Though CC is due to alteration in external forcing (natural factors or human activities), future projections consider the influence of only anthropogenic increases in greenhouse gases and other humanrelated factors $[3,4]$. Therefore, the twentieth century experienced the strongest warming trend of the last millennium with average temperatures rising by about $0.6{ }^{\circ} \mathrm{C}$ [5]. However, future temperature rises are likely to exceed this with a predicted rise of between 0.1 and $2{ }^{\circ} \mathrm{C}$ per decade $[6,7]$.

Biodiversity, agricultural production, and food security are predicted to alter expressively in response to a changing future climate globally [8-11]. Accordingly, the movement of plants to higher elevations and latitudes from the climate to which they are adapted is among the predicted consequences of CC [12]. There is now considerable evidence that such changes in plant distribution are occurring [13]. For example; rises in elevation have been reported in Alaska [14] Scandinavia [15], the Alps [16], and the Mediterranean region [17]. As species move towards higher latitudes and altitudes, populations at the leading edge of the species range are expected to expand and occupy new territory [18]. This resulted in a reduction of population sizes and extinctions at the contracting edge [13]. For those species where geographical limits are described by climate, poor reproduction, and survival at the pole-ward and upper altitudinal limits of distribution are likely to be amended by increasing temperatures. At the equatorial and lower altitudinal limit of its range, a species may replace through competitive exclusion, most likely influenced by both water availability and higher temperature $[19,20]$. However, changes in climatic conditions are likely to differ between continental and oceanic environments, possibly leading to a lack of range expansion and reductions [21].

$\mathrm{CC}$ has the potential to reduce species that are unable to track the climate to which they are currently adapted [12] and resulted in extinction risk [22]. However, the realized effect will differ greatly between different species. Consequently, the formation of novel communities in response to CC had been observed [13]. These communities are believed to result from differential migration rates during the past $\mathrm{CC}$ scenario [23]. Based on the similarity of species relationships with a changing climate in their past and present distributions, it has been suggested that adaptation has played only a minor role in the response of species [24]. However, the frequent differentiation of populations with respect to climate demonstrates that climate asserts strong selective pressure on natural populations [25].

CC affects species, and ecosystem composition and function both directly (increases in temperature, and changes in precipitation; water temperature and sea level) and indirectly (changes the intensity and frequency of wildfires) [26]. This species in both terrestrial and marine ecosystems are vulnerable to climate changes, and die out in their present areas and colonize new sites. At a changing climate in the future, there will be disruption of natural communities and extinction of species [27]. For example, high-diverse ecosystems, in Melanesia Islands, that has most of the diverse terrestrial ecosystems on the planet and contain over half of the world's species of coral, have been vulnerable to a changing climate, habitat degradation, fragmentation, and losses in the past 50 years [28].

Species have shown modification in their morphology, physiology, and behavior due to changes in climatic variables [29]. For example, painted turtles grew larger in warmer years and reached sexual maturity faster during warm sets of years [30]. Furthermore, the bodyweight of the North American wood rat (Neotoma sp.) has declined with an increase in temperature over the last 8 years. Besides, Juvenile red deer (Cervus elaphus) in Scotland grew faster in warmer springs leading to increases in adult body size [31]. Some frogs begin calling earlier (to attract mates) or call more during warm years [32]. Furthermore, there have been observed changes in types, intensity, and frequency of disturbances (e.g. fires, droughts, and blow-downs) due to $\mathrm{CC}$, and landuse practices [33]. They in turn affect the productivity and species composition, particularly at high latitudes and altitudes. The frequency of pests and diseases outbreaks have also changed in forest ecosystems because of changes in climatic variables [34]. Therefore, extreme climatic events and variability (e.g. floods, hail, freezing temperatures, tropical cyclones, and droughts) and the consequences of these (e.g. landslides and wildfire) have affected ecosystems as well. For example, climatic events such as the Eliño of the years 1997-1998 had major impacts on terrestrial ecosystems globally [32]. Likewise, human activities such as a change in land-use patterns, the degradation, modification, and fragmentation of ecosystems, exploitation of species, and the introduction of invasive species have aggravated CC impacts [26]. However, the relative impact of $\mathrm{CC}$ are likely to vary regionally due to variations in land use, biotic invasions, pollution, human activities, fire, and ecosystem types [35].

$\mathrm{CC}$ is expected to bring about long-term changes in weather conditions that have severe impacts on agricultural production and food security, availability, accessibility, and utilization [35]. Nevertheless, the impacts of 
$\mathrm{CC}$ on food security have tended to be viewed with most concern in locations where rained agriculture is still the primary source of food and income [36]. CC could have also an impact on the global food market prices. The higher market values for land and water, could result in payments to farmers for environmental services [37]. Therefore, the links between CC and food security have been explored in relation to impacts on crop productivity and food production [20,38]. For example, an increase in temperature was considered sufficiently detrimental that they would largely offset any increase in yield and growth as a consequence of increased atmospheric carbon dioxide $\left(\mathrm{CO}_{2}\right)$ concentration [39]. Therefore, it is evident that the changing climate will extremely affect the sustainable development goals [40-43].

Although sustainable food production is vital for sustainable development, it is now jeopardizing the accomplishments of sustainable development strategies and the 2030 Agenda for Sustainable Development [41, 42]. In this regard, the agriculture sector must improve its sustainability performance and adaptation to the impacts of climate change in ways that do not compromise global efforts to ensure food security [44-46]. Thus analyzing the impact of climate change on biodiversity and food security based on the global viewpoints as $\mathrm{CC}$ is a global phenomenon that requires global attention [46-48] is helpful. Therefore, the objectives of this review are to identify, appraise, and synthesize the scientific evidence on the link between CC, biodiversity, and food insecurity. Accordingly, the study is aimed to 1) Explore challenges and options of feeding the future in a changing climate and biodiversity loss scenarios, 2) Examine the impacts of $\mathrm{CC}$ on biodiversity and species' range shifts, 3) Explain and investigate an interactive linkage between biodiversity and food, 4) Analyze threats to biodiversity and their impacts, 5) Explain the adaptation and mitigation measures for a changing climate.

Analyzing approaches and strategies to mitigate a changing climate provides ways to reduce biodiversity loss and options of feeding a future $[46,49,50]$. This is also vital to illustrate the global CC and its multidimensional impacts on biodiversity and food security via actual scientific evidence. Moreover, the findings of this study are important for tracing, quantifying, and investigating current and predicted CC impacts on biodiversity and global food security for policymakers, researchers, and concerned bodies [51,52]. This updated scientific evidence and information on the global phenomena (such as CC, biodiversity loss, and food security) and the interaction and linkage among the components are helpful to have global solutions or insights [53]. Similarly, this paper is aimed to create a better understanding and communication among the scientific communities, researchers, national, and international policymakers about the links between CC, biodiversity, and food security [54]. Besides, it is aimed at providing up-to-date scientific evidence on CC impacts on biodiversity and food security, and its adaptation strategies. Therefore, CC, biodiversity loss, and food security require the combined concern and intelligence of all nations and communities [53, 55]. For this review, data and scientific outputs from the aforementioned publications were used via reinterpretation in the viewpoint of the impact of global CC on biodiversity and food security. Accordingly, the relevant and prevailing published articles were searched and used till 2021 to produce this paper. Quantitative data showing the numerical impact of $\mathrm{CC}$ on biodiversity and food security were taken from papers included in the review [56]. Besides, climate model-based scenarios and emissions scenarios developed previously have been used [35].

Nevertheless, the impact of CC on biodiversity and food security has been recognized, studies explaining, exploring, and analyzing its impacts are few compared to the magnitude of the problem globally [44]. Most studies emphasized the impact of CC on food security and agricultural production [57-60] excluding its impact on biodiversity which is a major source of food [61-63]. Besides, the existing few studies explore the impact of CC on biodiversity and food security separately at the smaller scale, at a certain area, and country [46, 64]. However, the present study is different from the existing ones by exploring these complex global phenomena (CC, biodiversity loss, and food security) in combination at a global level. Thus it tried to bring impacts from different settings. Therefore, the prevailing studies that illustrate the impact of $\mathrm{CC}$ on biodiversity and food security are too general to understand the magnitude of impacts and to inform adaptation strategies and policy development efforts [55, 65]. Moreover, this study provided challenges and options of feeding the future in changing climate and biodiversity loss scenarios, explained the adaptation, and mitigation measures for a changing climate, and species' range shifts which the other studies did not.

\section{Results and discussion \\ State of the global biodiversity}

The term biological diversity or biodiversity is defined as the "changeability between existing creatures from all bases counting, inter alia, terrestrial, marine, and other aquatic ecosystems and the ecological multiplexes of which they are part; this comprises variety in species, between species, and of ecosystems" [66]. Life has been on earth for at least three and a half billion years [67]. Though we are not sure exactly how many species exist on the earth right now, the total number of described species is assumed to be $10,000,000$ to $1,747,851$. However, 
some studies indicated that there are 100 million species inhabit and distributed the Earth [68]. Besides, from making it tough to describe, identify or distinguish a species from one another, over-exploitation and utilization of these species becomes a global challenge in recent days [69]. Therefore, species extinction may take place even without noting their presence or existence.

Biodiversity ensues in intensively and non-intensively managed ecosystems, respectively (agriculture, plantation forestry, and aquaculture) and (pastoral lands, native forests, freshwater ecosystems, and oceans) [70]. In both ways, it provides products such as food, medicines, materials, the ecosystem functioning services that are essential for life on earth (freshwater, soil conservation, and climate stability [71]. It also has intrinsic uses, irrespective of human needs, and interests.

\section{Causes of biodiversity loss}

The existence of life predominantly depends on the evaporative power of the atmosphere, along with solar radiation, carbon dioxide level, ambient temperature, and the availability of water and inorganic nutrients [72]. However, those important parameters upon which the existence of life depends are affected by humaninduced and natural factors. Consequently, over the last century, the rapidly expanding human population and economies place increasing demands on biodiversity resources [73]. One-third to one-half of the world's terrestrial surface has been substantially altered by human activity [74]. Species existing both at the Arctic and Antarctic environments are tainted by pollutants transported thousands of miles through the atmosphere. Thus, man is modifying the functioning of the entire planet, changing the earth's atmosphere through the industrial release of carbon dioxide (which may dramatically change the earth's climate) and diminishing the ozone layer through the production of chlorofluorocarbons [73]. Therefore, humans have endangered terrestrial and aquatic ecosystems, enhanced the survival of some species, and affected many organisms to adapt towards CC. Though there are a number of goods, and services derived from biodiversity (such as, pollination, soil biodiversity, biological control, and nutrient cycling), expansion and intensification of agriculture continue to be major causes of biodiversity loss $[75,76]$.

The impact of man on biodiversity includes species exploitation, land degradation, nitrogen deposition, pollution, introduction of invasive or alien species, water diversion, landscape fragmentation, urbanization, and industrialization [4, 73, 77-80]. However, recently the interaction of $\mathrm{CC}$ with pre-existing threats to the biota is the most serious and pressing problem above all. Habitat fragmentation, invasive species, pollution, overexploitation, and global CC are among the direct threats to the biodiversity (Table 1) [67]. On the other hand, the causes of biodiversity loss are more complex and interrelated with many other factors. Among which are overpopulation and overconsumption. This is compounded by social, economic, and political forces. Furthermore, socioeconomic structures, policies, weak governance, and legislation, corruption, and lack of enforcement, often intensify the threats to biodiversity [81].

Table 1 Threats to global biodiversity and their impacts

\begin{tabular}{|c|c|c|}
\hline Factors & Impacts on biodiversity & Sources \\
\hline Habitat loss and fragmentation & $\begin{array}{l}\text { Decrease in natural habitat, homogenization of species composition, fragmentation } \\
\text { of landscapes, and soil degradation }\end{array}$ & {$[40,67]$} \\
\hline Invasive alien species & $\begin{array}{l}\text { Competition with and predation on native species } \\
\text { Changes in ecosystem function } \\
\text { Extinctions and Homogenization }\end{array}$ & {$[28,37]$} \\
\hline Overexploitation & $\begin{array}{l}\text { Genetic contamination } \\
\text { Extinctions and decreased populations } \\
\text { Alien species introduced after resource depletion }\end{array}$ & {$[28,37]$} \\
\hline Climate change & $\begin{array}{l}\text { Homogenization and changes in ecosystem functioning } \\
\text { Extinctions } \\
\text { Expansion or contraction of species ranges }\end{array}$ & {$[28,37]$} \\
\hline Pollution & $\begin{array}{l}\text { Changes in species compositions and interactions } \\
\text { Higher mortality rates } \\
\text { Nutrient loading and acidification }\end{array}$ & {$[28,37]$} \\
\hline Anthropogenic threats & $\begin{array}{l}\text { species extinction } \\
\text { Habitat loss and conversion } \\
\text { Degradation and fragmentation } \\
\text { Over Harvesting }\end{array}$ & {$[82,83]$} \\
\hline
\end{tabular}




\section{Biodiversity and food: an interactive linkage and implications}

Bio-diverse ecosystems and biodiversity are critical for the survival of the world's food items and provide food for humans, animals, and all life forms. It is the foundation of all food industries and related services [84]. Human food forms derived from biodiversity resources include: vegetables, fruits, nuts, meat, and adjuncts to food in the form of food colorants, flavoring, and preservatives. These food forms may originate from wild or cultivated sources. From more than 300,000 flowering plant species, about 12,500 are considered to be edible to humans, although occasional use may embrace a much larger number [85], consisting around 200 species which have been domesticated for food. However, recently above $75 \%$ of the food supply for the human population is obtained, unswervingly or circuitously, from 12 types of plant species (bananas, beans, cassava, maize, millet, potatoes, rice, sorghum, soybean sugar cane, sweet potatoes, and wheat). For instance, the average global annual production for the years 1996-1998 was 2.07 billion tons of cereals, 0.64 billion tons of roots, and tubers [84].

Biodiversity provides an important safety-net during times of food insecurity, (at times of low agricultural production), seasonal food gaps [86], and at a period of climate-induced vulnerability [87]. Besides, it affords the maintenance of watershed services, soil fertility, pollination, seed dispersal, nutrient cycling, natural pest, and disease control $[4,76,88]$. These processes are critical to the maintenance of agricultural systems [20, 89]. However, most intensive agricultural systems seek to remove wild species as weeds, predators, and other pests that are not compromising production [90]. The immediate effects of intensification of agriculture leads to a decline in avian and pollinator diversity and numbers. This often leads to local extinction for habitat specialists [91, 92] primarily due to the homogenization of insect populations [93]. Thus commercial agriculture often favors synanthropic species (those that are adapted to live in anthropogenic landscapes), often causing a reduction in both species diversity and ecosystem function.

Although the diversity of animals that are exploited for food are more difficult to enumerate, a wide range of them provides products for consumption (e.g. milk and meat). Animals which humans use is made directly or indirectly include groups of insects (moths, beetles, wasps, and bees), crustaceans (lobsters, crabs, and shrimp), mollusks (bivalves, gastropods, and squid), echinoderms (sea urchins, and sea cucumbers) and vertebrates (fish, amphibians, reptiles, birds, and mammals) [84]. For example, from the years 1996-1998, 1.33 billion cattle, 1.76 billion sheep and goats, 0.12 billion equines, 0.18 billion buffaloes, and camels were maintained worldwide. Furthermore, global fisheries produce more than 80 million tons per year. While wild-harvested meat provides $30-80 \%$ of protein intake for many rural communities [94] mainly in the absence of domesticated alternative sources of protein. Likewise, more than $60 \%$ of the world's human population relies almost entirely on biodiversity medicine for primary health care [95]. While in many developing countries, this number ranges up to $80 \%$ [96]. However, species exploited remains narrow compared with their overall number, potential, and diversity. Furthermore, industrial-scale agriculture led to the loss of local genetic variations in crops, and livestock resulted to replacement by uniform varieties. This has been linked to the emergence and transmission of infectious diseases with deleterious impacts on human health and food security [4, 97]. Therefore, further exploitation and domestication of wild species relatives and varieties will be helpful to broaden the genetic bases [98-100]. Besides, wild relatives may improve crop resilience to biotic and abiotic stresses.

One billion people rely on wild-harvested products for nutrition and income globally [101]. In India alone, the livelihoods of around 6 million people depend on harvested forest products [102] as India has one of the most diverse and luxuriant tropical vegetation conditions in the world ( $72 \%$ are tropical moist deciduous, dry deciduous, and wet evergreen forests) $[103,104]$. In areas that lack basic infrastructure and market access, the collection of wild resources provides considerable subsistence support to local livelihoods [105]. In addition, the harvest and sale of wild products often provide one of the only means of access to the cash economy [106]. Though today's modern crop and livestock varieties are derived from their wild relatives, natural and manmade threats to habitats and farming systems make imperative to collect, conserve and characterize traditional varieties (landraces) and wild relatives [78, 107, 108]. However, from 1100 wild plant species, $15-37 \%$ of them are in danger of extinction [22]. Besides, though agriculture is the main cause of deforestation, forest biodiversity is vital to food security as it provide diversified foods and supply the energy needed to cook food for a third of the world's population [48]. Furthermore, 16-22\% of wild relatives of species with direct value to agriculture are in danger of extinction [109]. Being 30-40\% world's biodiversity outside protected areas, under sort of agricultural, in complex multi-functional landscapes occupied by people and their associated farming systems aggravated the extinction problem [63].

\section{Climate, climate change, and variability}

The term climate is defined as "the average weather condition, characterized by long-term statistics (typically 
three decades) (mean values, variances, and probabilities of extreme values) for the meteorological elements in a given area" [1]. These magnitudes remain external variables such as temperature, precipitation, and wind. Though there is no agreed definition for the term "climate variability" it is the inherent characteristic of climate that manifests itself as changes of climate over time. The grade of climate inconsistency could labelled through the alterations among long-term statistics of meteorological rudiments intended for dissimilar periods. Furthermore, the term is often used to denote deviations of climate statistics over a given period (such as during a specific month, season, or year) from the long-term climate statistics relating to the corresponding calendar period [110]. However, for meteorologists and climatologists, climate variability refers only to the year-to-year variations of atmospheric conditions around a mean state. Climate variability can interact with pressures from human activities [111]. For example, the extent and persistence of fires such as those along the edges of peat-swamp forests in southern Sumatra, Kalimantan, and Brazil during recent Eliño events show the importance of the interaction between climate and human action.

Though there is no internationally agreed definition of the term "climate change" it can refer to the "variation in climate over time' [32, 40]. Change in the climate has resulted in hazardous life occurrences including hurricane, drought, tornados, blizzard, or monsoon. CC refers to the rapid changes in earth system dynamics that have been occurring at an increasing rate over the past two or more centuries [112]. The term encompasses all forms of climatic inconstancy (i.e. any differences from long-term statistics of the meteorological elements calculated for different periods but relating to the same area), regardless of their statistical nature or physical causes [110]. In a more restricted sense, it denotes a significant change in (economic, environmental, and social effect) and in the mean values of a meteorological element (temperature or amount of precipitation) in the course of a certain period, where the means are taken over periods of a decade or longer [1]. The climate of the earth has been in a persistent condition of alteration through the earth's 4.5 billion-year antiquity, however, most of these variations happen on astronomical or geological time scales and are too slow to be observed on a human scale [112].

Until the industrial revolution, CC occurred because of natural forces acting on the climate system, and these forces are still at work [113]. However, on an astronomical time scale, the earth's climate system alternates between cold conditions that support large-scale continental glaciations and warm conditions that make the planet extensively tropical and lacking in permanent ice caps. Evidence suggests that this behavior is due to cyclical changes in the position of the earth's orbit around the sun and the angle of its rotational axis, usually referred to as "astronomical forcing of climate" [114]. Furthermore, natural powers that are supposed to pay to variations in the climate system on a geological time scale are sunspot activity, meteorite bombardment, erosion, earthquakes, volcanic activity, mountain building, movement of sea beds, and ocean trench formation [115]. Variations in the concentration of GHGs due to natural geological processes have created alternating periods of glacier advance and glacier retreat (interglacial) within the longer astronomical cycles [116]. However, average weather and features of the earth's atmospheric environment have been changing rapidly during the past few centuries, due to technological advances and rapid population growth, and which have led to deforestation, erosion, desertification, urbanization, industrialization, pollution, fossil fuel depletion, and overfishing [111]. Therefore, the anthropogenic CC has gradually emerged since World War II due to the availability of cheap fossil fuels. Accordingly, mean global temperatures have been increasing since 1850, owing to the accumulation of GHGs in the atmosphere due to the burning of fossil fuels, and the spread of intensive agriculture [117].

\section{Impact of climate change on biodiversity}

The three main variables of $\mathrm{CC}$ (elevated $\mathrm{CO}_{2}$, altered rainfall patterns, and temperature ranges) aggravate seawater rise; drought, heatwaves, wildfires, storms, and floods [118]. Increasing the global temperatures by $0.798{ }^{\circ} \mathrm{C}$ and concentration of $\mathrm{CO}_{2}$ level from 280 to $379 \mathrm{ppm}$ equivalent on pre-industrial levels would have an impact on timing seasons of flora, and fauna [119]. Furthermore, changes in temperature, flooding, and sea level rise will change ecosystems. Likewise, changes in rainfall and temperatures will increase species extinction rates [120]. Therefore, expansion of species ranges (migration); changes in species compositions and interactions (adaptation); changes in resource availability; spread of diseases to new ranges; changes in the characteristics of protected areas; and changes in the resilience of ecosystems are among impacts of $\mathrm{CC}$ on biodiversity [64, 121]. In addition, CC through alteration of precipitation, temperatures, and flooding is exerting more pressure on habitats and species. It directly affects the growth and behavior of organisms, modifies population size and age structure, and affects decomposition, nutrient cycling, water flows, species composition, and interactions [64]. It may also indirectly affect species and ecosystems through altering water flows, dryland salinity, and the frequency of extreme climatic events (floods, hail tropical cyclones, and ocean acidity) [122]. Moreover, $\mathrm{CC}$ indirectly changes the disturbance regimes of an 
area. Therefore, species displaced by competition may fail to survive under a changing climate [122]. For example, the extinction rate of mammals for the period 1600 A.D.-2000 A.D. have been 50-100 times higher than the background rate for mammals estimated from the fossil record [123].

A greater number of species over 50 to 100 years will either need to migrate rapidly to keep up with changing conditions or face extinction due to $\mathrm{CC}$. It has been estimated that the earth is losing species at the rate of three every hour and 30,000 species per year [84]. Therefore, nearly $99.9 \%$ of life that existed on earth has gone to extinction in the past due to natural and manmade factors [124]. However, current rates of extinction are estimated to be 100 to 1,000 times faster [125]. Forecasts predict that between 17 and 35 percent of species on earth will become extinct in the next 100 years. For instance, 27 percent of the world's coral reefs had been degraded by increased water temperatures, with the largest single cause being the climate-related coral bleaching event of 1998 [61]. Furthermore, CC alters the timing of biological events such as phenology. For example, modifications in the timing of emergence, growth, and reproduction of cold-hardy invertebrate species were because of warmer conditions during autumn-spring [126]. Accordingly, between the years 1978 and 1984, two frog species at their northern range limit in the United Kingdom started spawning 2-3 weeks earlier [64, 127]. Furthermore, bird species in Europe, North America, and Latin America had start breeding earlier due to CC. For example, in Europe, egg-laying has innovative above the previous 23 years; in the United Kingdom, 20 of 65 species, counting long-distance migrants, advanced their egg-laying dates by an average of 8 days among the years 1971 and 1995. Consequently, variations in insect and bird migration through earlier arrival dates of spring migrants in the United States, later autumn departure dates in Europe, and changes in migratory patterns in Africa and Australia is the result of CC [40].

$\mathrm{CC}$ will lead to animal extinction and migration [22]. Migratory mammalian species such as the Fennec fox are forced to search harsh environmental conditions to survive because of CC. Rare bird species such as Hubara bustard are under severe pressure and extinction. The phonological effect of $\mathrm{CC}$ will also impact the seasons for bird migration [128]. Some mammalian species such as rodents could also be affected in terms of population dynamics and distribution. Furthermore, CC may likely change the migratory ways and period for species that use seasonal wetlands (e.g. migratory birds) and track seasonal variations in vegetation (e.g. herbivores). This may increase conflicts between people and large mammals such as elephants, particularly in areas where rainfall is low [129]. Subsequently, change in the intensity and duration of the rainy vs. dry seasons could change breeding rates and genetic structures in those populations [128].

Wild, narrowly adapted, and endemics species are vulnerable to $\mathrm{CC}$ as they do not receive management interventions [48]. For example, African elephants (Loxodonta africana), breed year-round, however, dominant males mate in the wet season and subordinate males breed in the dry season. In contrast, invasive species with high fertility and dispersal capabilities have been shown to be highly adaptive to variable climatic conditions [127]. Therefore, strategies for future designations of protected areas and projections of future CC need to be developed in the geographic range of plant, and animal species to ensure adequate protection. Furthermore, $\mathrm{CC}$ will alter the patterns of net primary production and change the growing conditions of species. For example, earlier flowering and lengthening of the growing season of some plants (e.g. across Europe by about 11 days from the years 1959 to 1993) had observed [130]. Therefore, in the long term speciation and extinction events may associate with $\mathrm{CC}$, although moderate oscillations of climate do not necessarily promote speciation despite forcing changes in species' geographical ranges [48].

Biodiversity in arid land which is a vital biological capital is affected by CC. For example, growth in shrub, and grassland vegetation depends highly upon the timing, intensity and duration of rainfall. Those species have root systems that are shallow and dense. These plants draw their moisture from water that is available in upper soil layers and during dry months, less precipitation will occur likely reducing the resilience of these plants [131]. Thus the driving force for bio-diversification in drylands is water, soil nutrients, drought, salinity, herbivore, pressure, and fires. Consequently, the degradation of vegetation cover decreases the carbon sequestration capacity of drylands. Thus this increases emissions of $\mathrm{CO}_{2}$ into the atmosphere. Furthermore, the loss of vegetative cover in the arid lands increases suspended dust in the atmosphere. Therefore, CC affects drylands biodiversity by influencing species distribution range, water supplies, heat extremes, humidity, and temperature of soils, and the albedo [132]. An increase in temperature by $38{ }^{\circ} \mathrm{C}$ will increase the evapotranspiration rate due to warmer conditions, which would result in drier soil. Therefore, warming would lead to a decrease in plant productivity in such areas. For instance, in East Africa, grass and shrub savannahs, are known to be highly sensitive to the shortterm availability of water due to climate variability [131]. Furthermore, deciduous and semi-deciduous closedcanopy forests may be very sensitive to small decreases in precipitation during the growing season in Africa. 
Subsequently, deciduous tropical trees suffer severe water stress at the beginning of the growing season, and that a warmer climate may accelerate the depletion of deep-soil water that tree species depend on for survival [133].

The projected rapid rise in temperature and destruction of habitats could easily disrupt the connectedness among species, transforming existing communities, and movements of species. These will lead to extinction of species [127]. However, species that have the capability to keep up with climate shifts may survive; others that cannot respond will likely suffer. For example, deciduous and semi-deciduous closed-canopy forests in Africa may be very sensitive to small decreases in the amount of precipitation during the growing season. This illustrates that deciduous forests may be more sensitive than grasslands or savannahs to reduced precipitation [134]. For example, ecosystems that are comprised of uniform herbaceous covers such as savannah plant communities show the highest sensitivity to precipitation fluctuations compared to diverse communities with a mix of herbaceous, shrubs, and trees [131].

\section{Climate change-driven species' range shifts}

A range is a geographical area where a species can be found. It is determined by climate, soil type, and species interactions [135]. Over geological timescales, adaptive radiation, speciation, and plate tectonics can also influence the range of a species. The range of a species can shift owing to one or more changes in climate warming, land-use change, new ecological connections, or artificial introductions of the species to a new environment [18]. However, if the land-use change is the main driver, species' range shifts would occur in more directions. Historically, CC has resulted in dramatic shifts in the geographical distributions of species and ecosystems [136]. However, the recent amounts of species migration could have to be much higher than postglacial periods for species to adapt [127]. Nevertheless, many reports on current massive range shifts of species suggest that climate warming is a key driving factor [136-139]. A meta-analysis approach showed that the dissemination of species have recently shifted to higher elevations at a rate of $11.0 \mathrm{~m}$ per decade, and to higher latitudes at a rate of $16.9 \mathrm{~km}$ per decade. These rates are approximately two to three times faster than previously reported [140].

If climatic factors such as temperature and precipitation change in a region go beyond the tolerance of a species, the distribution changes of the species may be inevitable [141]. Furthermore, changes in plants' range have the potential to not only affect species distribution but also render many species unable to follow the climate to which they are adapted (Fig. 1). For example, shifts from one climate zone to another could occur in half of the world's protected areas, with the effects more pronounced in those at higher latitudes and altitudes [142]. Climatically associated shifts in species ranges have been noted on most continents, such as in the Polar Regions, and within major taxonomic groups of animals (i.e. insects, amphibians, birds, mammals and plants). For example; the ranges of the sampled butterfly species both in Europe and North America have been shifted poleward and up due to temperatures raise. A study of 35 non-migratory butterflies in Europe showed that over $60 \%$ shifted north by $35-240 \mathrm{~km}$ over the twentieth century [140, 143]. The population of several species of forest butterflies and moths in central Europe in the early 1990s, including the gypsy moth (Lymantria dispar), have been linked to increased temperature, as have poleward range expansions of several species of damsel and dragonflies (Odonata) and cockroaches, grasshoppers, and locusts (Orthoptera). Besides, the spring range of Barnacle Geese (Branta leucopsis) has moved north along the Norwegian coast. In South Africa, a reduction in the range of a species is likely to have an increased risk in local extinction [144]. This could be due to the positive inter-specific relationship between population size and the range size. If range size decreases, there will be a rapid decline in population size.

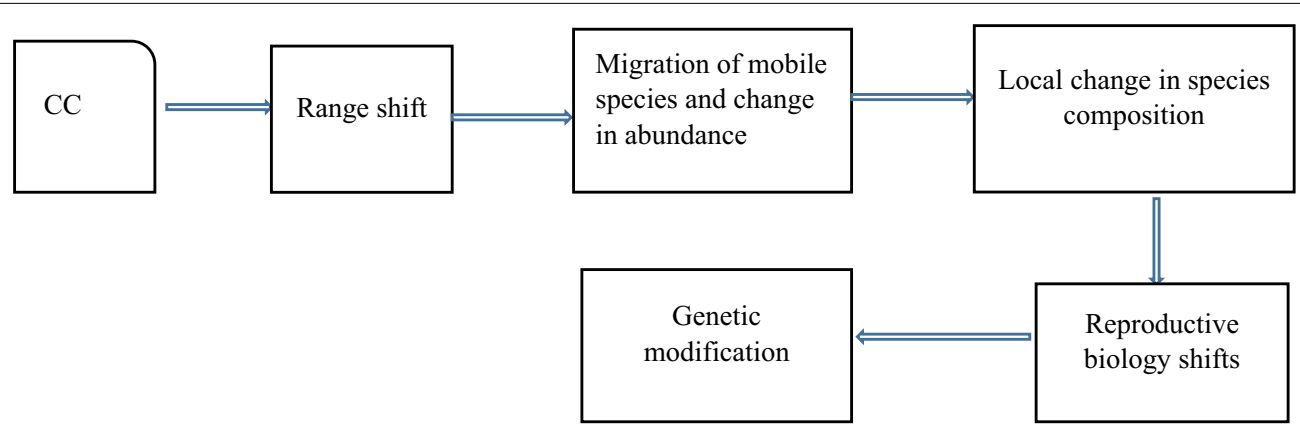

Fig. 1 Strategies that enable species to persist in a changing climate 
Climate change-driven species' range shift responses may depend on species types and altitude. For instance, along an elevation gradient of 2400 and $2500 \mathrm{~m}$ above sea level, shrubs expanded 5.6\% per decade [145]. Nevertheless, even in low-altitude areas, the effects of warming can be detected over a 20-year period [146]. At a subarctic island, analyses of 40 years of species data revealed an average upward elevation shift of half of the plant species [147]. Curiously, although the species that determined the pattern of upslope expansion may be considered highly responsive, the response is still lower than expected based on the rate of warming. Such speciesspecific range shift responses may result in non-equivalent communities at higher elevations, consisting of the original plant species and the range expanders. Furthermore, downhill species shifts have also be observed, for example in California where the water deficit at higher elevations increased over time [148].

Range shift distances are relatively short in altitudinal gradients [149]. Similarly, patterns of latitudinal range shifts have been predicted based on the altitudinal shifts [150]. Thus climatic effects of $1 \mathrm{~m}$ in altitudinal range shift may be considered equal to $6.1 \mathrm{~km}$ in latitudinal shift [142]. For instance, in northwestern Europe, large vertebrates are much more limited in migration now than they were in the past [151]. Such limitations may also apply to insect range shifts. Furthermore, range expansion by habitat-specialist butterflies was constrained following climate warming because the specific habitats lacked connections [152]. For example, in a comparison of nematodes and microbial assemblages among 30 chalk grasslands in the United Kingdom roughly scattered across a west-east gradient of $200 \mathrm{~km}$, the similarity in both nematodes and bacteria declined with distance [153]. Hence, range shifts in any direction can expose that species to novel soil biota and disconnect it from the usual biota with which it interacts [154].

In a 44-year study (1965-2008) of climate warming in lowland and highland forests in France, latitudinal range shifts were expected in the lowland forests. Consequently, in lowland forests, the responses of latitudinal range shifts were 3.1 times less strong than those of altitudinal range shifts in highland forests [155]. This could be due to lowland forests that may have proportionally more species that are persistent in the face of warming. Similarly, fewer opportunities for short-distance escapes or the greater habitat fragmentation in lowlands may prevent range shifting. Range-shifting tree species from a temperate forest in Canada, such as red maple (Acer rubrum), can establish in a boreal red pine (Pinus resinosa) forest only if there are large tree-fall gaps [156]. Native red pine forest species, in contrast, were not influenced by gap size or gap age. The spread of species from tropical forests to cooler areas may be constrained by long dispersal distances and poor colonization sites along the dispersal routes. This is because of tropical climate now is warmer than at any time in the past two million years [157]. Even though range shifts of species from tropical lowlands to highlands are possible, it may result in depauperate lowland plant communities, which will be increasingly dominated by early successional species [138]. Therefore, species ranges are likely to become more fragmented as they shift in response to CC. For example, up to $66 \%$ of species may be lost due to predicted range shifts caused by CC in South Africa's Krueger National Park [158].

Drivers of range shifts other than climate change Species' range shifts have occurred throughout the Earth's history. For instance, glacial cycles have caused the species' range alterations [159]. There have been approximately 20 cycles of glaciation and deglaciation during the Quaternary (the last 2.58 million years), particularly in the Northern Hemisphere [160]. Based on pollen records from late Quaternary Europe, pale vegetation maps have been constructed at the level of formations. However, macroclimate in the late Quaternary might have been completely different from the present one [161]. Nevertheless, compared with historical geographic range shifts such as those that have taken place during Glaciation-deglaciation cycles over the past two million years, the rate of current climate warming is unprecedented [150].

Species abundance can be influenced by resource availability, predation, propagule availability, symbioses, competition, and facilitation. As all these factors may vary between the old and new ranges, species that can move may not necessarily encounter suitable circumstances for establishment, growth, and reproduction [29]. Moreover, these factors may also vary after a species has been introduced to a new range, which can affect community composition in a dynamic way. Therefore, species interactions can drive evolution as seen in highly specialized pollination, parasitism patterns and in other symbiotic mutualisms. CC may also disrupt those evolutionary processes as well as initiate new processes [162]. However, investigators have not yet determined how adaptation, and migration interact during range shifts [29].

Causes of range shifts other than climate warming or cooling factors may include; intensified grazing and fire regimes as in the case of expansion of shrubs in Colorado [163]. Whereas the Elino in Southern Oscillation influences the frequency and extent of wildfires, which in turn influence tree stand composition in the southern United States [164]. Furthermore, there are examples of birds range expansion owing to land-use change [165]. While improved feeding or nesting sites can also drive 
such range shifts. For example, the Black-shouldered Kite (Elanus caeruleus) has shifted range northward into Spain because, during the last half of the previous century, cultivated Dehesa systems became more similar to African savannahs, where this species originated [166]. However, habitat fragmentation caused by intensified land use can limit the capacity of species' range shifts. It might have also limited range shifts in postglacial periods under specific conditions [167].

\section{Climate change-driven migration, gene flow, and habitat fragmentation}

The most rapid responses of individuals in populations subjected to CC are likely to be phenotypic [168]. However, in subsequent generations, natural selection acting primarily during plant establishment will lead to some degree of adaptation, assuming that genetic variation for the traits under selection exists within the population [169]. Considering adaptation as primarily dependent on extant variation, the migration of plant species in response to rapid climatic warming will frequently be slower than phenotypic and adaptive genetic changes, because of the uncertainties of population establishment [170]. Migration involves the physical dispersal of propagules such as seeds, plant fragments and the successful establishment of new populations in previously unoccupied territory. Arriving propagules to the new site will be filtered out by a process of natural selection [12]. However, the adaptation to local conditions is often inherent in migration. Thus as the climate warms, individuals from populations throughout the species range are likely to establish at higher altitudes and latitudes.

Migration will occur throughout the species range in the form of both propagule and pollen dispersal, not simply as a result of expansion and contraction at the range margins [12]. However, for a plant species to migrate across a landscape, its habitat patches must be sufficiently well connected to allow gene flow by pollen and propagule between populations. Nevertheless, in the heavily fragmented landscapes that have resulted from the activities of humankind, this may not always be possible, leading to the fragmentation of species ranges and genetic isolation of populations [171]. Therefore, demographic factors such as altered mating systems and changes in pollinator behavior resulted in a reduction of individual fitness and increased risk of population extinction [172]. However, species capable of migrating at unlimited rates are more likely to survive than those that migrate more slowly [173]. For example, extinction rates of 1103 species in diverse parts of the world under these two migration scenarios, providing extinction rates of $21-23 \%$ with unlimited migration and $38-52 \%$ with no migration [174]. The effects of habitat fragmentation are compounded by demographic stochasticity and the inherently poor dispersal of many species [172]. Therefore, the probability of population establishment declines rapidly with increasing distance between habitats patches [175].

Population isolation is a feature of many communities that occur in natural habitat islands such as high alpine ecosystems, where migration between populations is absent or extremely restricted [176]. Habitat fragmentation and consequent population isolation pose particular problems for species subject to rapid climatic changes as isolated populations may leave outside their optimum climate space [171]. For example, the climatic response of the species such as Pinus contorta and Pinus sylvestris suggests that this decoupling of climate and local adaptation may significantly decrease both the growth and survival of individuals [177]. Therefore, species ranges are likely to become more fragmented as they shift in response to $\mathrm{CC}$. For example, up to $66 \%$ of species may be lost due to predicted range shifts caused by CC in South Africa's Krueger National Park [158].

\section{Climate change-driven genetic variability and phenotypic plasticity within-population}

The responses for $\mathrm{CC}$ arises not only among populations throughout a species range but also between co-occurring individuals within a population [178]. For instance, there is a significant micro-geographical genetic differentiation of populations of Triticum dicoccoides (wild emmer wheat) in response to climate (solar radiation, temperature, and aridity stress) over distances of several meters within a habitat mosaic. A similar pattern has been reported in Hordeum spontaneum (wild barley) [179]. Within-population differentiation can be detected using microsatellite, randomly amplified polymorphic DNA and allozyme molecular markers across spatial scales ranging from $<10 \mathrm{~m}$ up to $1 \mathrm{~km}$. Different genotypes establish preferentially in warmer and cooler years [180]. These cool year and warm year genotypes are intermixed within the same populations, despite presumably high levels of gene flow between neighboring species. Further examples of micro-geographical adaptive differentiation of species with respect to climate are found in Picea engelmanii (Engelmann spruce), Pinus edulis (pin on pine), and Pinus ponderosa (ponderosa pine) [181].

Climate-related genetic differentiation occurred across a variety of different species such as Betula pendula and Betula pubescens lengthen growing season as the climate warms [182]. Populations contained considerable levels of heritable variation for budburst date, the levels were inadequate to allow date of budburst to track forecast changes in climate. Although genetic variation for the traits is high, the rapid rate at which warming 
is predicted to occur will outstrip the potential rate of adaptive evolution in Pinus sylvestris species [183]. Therefore, adaptation to future climates may require the simultaneous evolution of a number of different traits that may constrain by correlations between them [184]. The annual legume Chamaecrista fasciculata was unable to respond fast enough to track predicted conditions, despite the existence of significant levels of variation for the quantitative traits investigated [25]. While a shortlived outcrossing annual such as Brassica juncea experimental populations failed to respond either genetically or phenotypically to simulated CC in any of five fitnessrelated traits [185].

The potential response of population to a changing climate will in part be governed by the average lifespan of individuals and the age at which they reach reproductive maturity. However, delayed reproductive maturity will reduce the number of generations that can establish during any given period of time, whilst the long lifespan (and hence low turnover) of individuals will reduce the opportunities for the establishment of new genotypes within existing populations [183]. For populations that show little potential for an in situ adaptive response to CC, gene flow from populations in warmer areas of the species range will be of critical importance in permitting adaptation to their new conditions [182]. Conversely, for many species, gene flow between populations may be critically low because of the effects of habitat fragmentation [186].

Phenotypic plasticity is an essential component of plant response to an ever-changing environment. The term phenotypic plasticity is used to describe the differences in an organism's physiology, morphology, and development that arise in response to changes in its environment, thereby encompassing reversible (acclamatory) and non-reversible phenotypic changes [187]. Plants respond to changes in their environment over several generations via genetic change. However, when environmental variation occurs on a timescale shorter than the life of the plant any response must be in terms of a plastic phenotype [188]. If the possession of a plastic phenotype buffers individuals against short-term environmental fluctuation, then it might be expected that phenotypic plasticity could buffer individuals against the long-term effects of CC. This would reduce the genetic and distributional changes that we might expect based on the species-typical climate response [189]. Therefore, species may able to adapt autonomously to $\mathrm{CC}$ by dispersing to suitable habitats, changing their phenotype, and genetic change over generations [170, 190]. However some species will be able to adapt better than others, depending on generation times, ability to disperse, and dependency on other species. For example pollinators, hosts for parasites and symbiosis association [191]. Therefore, in future climatic scenarios, plant species will tend and are expected to tolerate a changing climatic conditions. This would require individuals to possess near-perfect plasticity, tolerating all changes in climate with no apparent fitness costs [192]. However, such widespread plastic tolerance of changing climate is not typical [13,17].

Both the occurrence and magnitude of phenotypic plasticity for any trait are themselves characteristics that are under genetic control, with levels varying between traits, individuals and populations [193]. Although a plastic phenotype will allow plants to respond to climate fluctuations over the lifetime, the capacity for a plastic response to an event weakens for events of greater extremes experienced at longer time scales [194]. However, species capacity to respond to environmental change by phenotypic plasticity has its limits [190]. Consequently, there will be selection pressure on many plants for an increased plastic response to future climate [194].

\section{Effect of climate change on food security}

Food security will be maintained when "access to food by all people at all times is adequate for an active and healthy life" [195, 196]. Biodiversity is a key source of food [197]. If biodiversity is negatively affected by $\mathrm{CC}$ it goes to show that the world food security is greatly threatened stemming from an imbalance in the natural ecosystem [198]. Therefore, concerns over species extinction are warranted because of the goods and services provided by species such as pollination, natural pest control, food, and medicine. CC is affecting those goods, services, and ecosystem resilience through hurricanes, blizzards, heat waves, drought, and extreme weather events [199]. For example, rainfall and Elinio events between 1996 to 2003 [200] produce high amounts of precipitation in parts of equatorial, East Africa, and resulted in flooding, reduction of crops, and agricultural yields. Therefore, change in climatic effects has immediate impacts on food production and distribution [48]. Moreover, changes in mean temperatures and rainfall will affect the suitability of land for crops, pasture, and productivity of marine resources. It will also increases the incidence of pests and diseases; loss of biodiversity, a decline of ecosystem functioning; reduce the availability of water for crop, livestock, and inland fish production, groundwater depletion, and sealevel rise [201].

Globally, CC is expected to reduce cereal production by 1 to $7 \%$ by 2060 [202]. Besides, $22 \%$ of the cultivated area under the world's major crops is likely expected to practice adverse impacts due to CC by 2050 [203]. Accordingly, CC is expected to lead to 5-170 million additional people being at risk of hunger by 2080 [204]. Therefore, $\mathrm{CC}$ through its extreme and unpredictable weather will affect food security and crop yields too [11, 205]. It is 
estimated that agricultural yields in Africa alone could decline by more than 30 percent by 2050 [206]. Such yield reduction will largely distress the poor people who are less capable of absorbing the global commodity price changes that characterize a reduction in supply [207]. Three of the most recent famines in sub-Saharan Africa were exacerbated by unexpected weather patterns that pushed already vulnerable livelihoods into major food insecurity and famine [208]. Furthermore, CC through extreme weather events can have a devastating effect on crops as the recent droughts in Russia and China, and floods in Australia, India, Pakistan, and Europe indicated [209]. Therefore, the impacts of rising temperatures will likely hurt the rural poor too [206]. Furthermore, growing extreme weather events makes it highly likely that asset losses attributable to weather-related disasters will increase [210]. These losses involve loss of life and food security status of millions of people in disaster-prone areas. For example, an average of 500 weather-related disasters is now taking place each year, compared with 120 in the 1980s. Similarly, the number of floods has increased over the same period [211].

$\mathrm{CC}$ affects food security for communities that depend on rain-fed agriculture making food security highly vulnerable to climate variability such as shifts in the growing season [48, 201, 212]. For instance, from the year 1996 to 2003, there has been decline $50-150 \mathrm{~mm}$ rainfall per season (March to May) and failure in long-cycle crops (e.g. slowly maturing varieties of sorghum and maize) [200]. For example, in Zimbabwe, past Eliño events and warm sea surface temperatures in the eastern equatorial Pacific reduce $60 \%$ of agricultural production of maize [213]. If agricultural production in the low-income developing countries of Asia and Africa is adversely affected by CC, large numbers of the rural poor will be vulnerable to food insecurity too. Thus, food processing, distribution, acquisition, preparation, and consumption are affected by $\mathrm{CC}$ as well. Moreover, as the frequency and intensity of severe weather increase, there is a growing risk of storm damage to transport and distribution of food items [214]. Therefore, CC affects the four components of food security (food availability, food accessibility, food utilization, and food system stability) [58]. In direct and indirect ways, CC variables influence biophysical factors (plant and animal growth, water cycles, biodiversity and nutrient cycling), and the ways in which those are managed for agricultural practices, and food production [215]. Furthermore, $\mathrm{CC}$ induced variables have a large impact on physical and human capital (roads, storage, and marketing infrastructure, houses, productive assets, electricity grids, and human health). These indirectly fluctuate the economic and socio-political factors that govern food access and utilization [216].
Change in climatic variables will alter suitable areas for the cultivation of a wide range of crops. Current and projected climate data for about 2055 under the climate model based scenarios, indicate the impacts of CC on areas that are suitable for several staple and cash crops [217]. Therefore, there will be losses in a suitable areas in sub-Saharan Africa, the Caribbean, India, and northern Australia, and gains in the northern USA, Canada and most of Europe. Consequently, 23 crops are forecasted to gain fit areas while 20 are predicted to lose. Even though similar trends in sub-Saharan Africa have been predicted, developed nations will perceive a considerable expansion of suitable arable land to higher altitudes and the potential to increase production if those lands are brought under cultivation $[218,219]$. Therefore, areas that are currently most food-insecure will be most affected by $\mathrm{CC}$, and have the greatest need for new crop varieties tolerant of extreme climate conditions such as drought, heat, submergence, and salinity [59].

The impact of $\mathrm{CC}$ on food production must take into account the characteristics of the agro-ecosystems [220]. For example, moderate warming (increases of 1 to $3{ }^{\circ} \mathrm{C}$ in mean temperature) is expected to benefit crop and pasture yields in temperate regions, while in tropical and seasonally dry regions, it is likely to have negative impacts on cereal crops. However, warming more than $3{ }^{\circ} \mathrm{C}$ is expected to have negative effects on Agricultural production in all regions. Furthermore, increases in air temperature can accelerate crop growth and consequently, shorten the growth period. Conversely, such changes can lead to poor verbalization and reduced yield [221]. Therefore, CC may pose a threat to food security through erratic rainfall patterns and decreasing crop yields, contributing to increased hunger [11, 20, 222, 223]. Crops have thresholds beyond which growth and yield are compromised for climatic variables such as rainfall, soil moisture, temperature, and radiation [20, 224]. For example, cereals and fruit tree yields can be damaged by a few days of temperatures above or below a certain threshold [225]. Similarly, in the European heatwave of 2003, when temperatures were $6{ }^{\circ} \mathrm{C}$ above long-term means, crop yields dropped by $36 \%$ in Italy, and by $25 \%$ for fruit and $30 \%$ for forage in France [226]. Therefore, changing climatic conditions could create crop losses, resulting from contamination with microorganisms and their metabolic products. This could lead to a rise in food prices. Furthermore, it increased the intensity and frequency of storms, altered hydrological cycles, and precipitation [227]. Transport infrastructure is affected by CC too [228]. Heat stress and increased frequency of flood events destroy infrastructure in developing countries [229]. This has an impact on food distribution and influence people's access to markets to sell or purchase food products [230]. Thus, 
declines in productivity of cropland could occur, with the severest impacts in the currently food-insecure areas of sub-Saharan Africa, which have the least ability to adapt to $\mathrm{CC}$ or to compensate through greater food imports [2].

Poor people will be exposed to greater variability in and uncertainties about food in a changing climate. Non-farming low-income rural and urban households whose incomes fall below the poverty line because of CC impacts will face similar choices [212, 223, 231]. Most food is not produced by individual households but acquired through buying, trading, and borrowing [232]. CC impact on income-earning opportunities can affect the ability to buy food, and a changing climate or climate extremes may affect the availability of certain food products, which may influence their price. For example, in Cameroon, Haiti, Tunisia, and Egypt, there have been increased prices of basic foodstuffs [233]. The change in seasonality attributed to $\mathrm{CC}$ can lead to certain food products becoming scarcer at certain times of the year $[234,235]$. These seasonal differences in the food supply, make human life vulnerable at certain times of the year. Many areas will receive less annual rainfall, while others may receive much due to CC [236]. In low latitude regions, moderate temperature increases $\left(1-2{ }^{\circ} \mathrm{C}\right)$ are likely to have negative impacts on yields of the major cereals [237]. Furthermore, warming will have increasingly negative impacts on all regions. In cereal cropping systems, changing varieties and planting times will cause a $10-15 \%$ reduction in crop yield corresponding to a $1-2{ }^{\circ} \mathrm{C}$ local temperature increase. Consequently, the pressure to cultivate marginal land may increase land degradation. For instance, there was a 5\% decrease in the yield of rice as a consequence of warming for above $32.8^{\circ} \mathrm{C}[238]$.

CC may increase extinction risks for underutilized plant species such as species suitable for biofuel production (biodiesel, and ethanol technologies) [239]. Species and genetic variety used for food (including wild species) and the direct ecosystem services that support agriculture, including services such as pollination and nutrient cycling are affected by CC too [109]. For instance, pollination is likely to be problematic, as insect response to $\mathrm{CC}$ is particularly sensitive. Besides, CC may have profound impacts on the synchronicity between pollinators and crop flowering, resulting in reduced productivity. The projected impacts of $\mathrm{CC}$ on wild plant species distribution will affect the composition of plant and animal communities, and biological control organisms as well [22]. In warmer environments, CC may result in more intense rainfall events between prolonged dry periods, as well as reduced or more variable water resources for irrigation. Such conditions may promote pests and disease on crops and livestock, as well as soil erosion, drought, and desertification [80,88, 240]. Conflicts over water resources due to $\mathrm{CC}$ will affect food production, animals' fodder, and people's food access in affected areas too [241]. Furthermore, drought and deforestation can increase fire risk, with consequent loss of the vegetative cover needed for grazing and fuelwood [242]. For example, droughts increase livestock mortality in African countries between 1980 and 1999 (Table 2).

Warming temperatures may negatively affect fisheries by faster depletion of the limited oxygen and Lake Overturn [252]. Consequently, many tropical fishes have evolved to survive in very warm water. However, they cannot survive at temperatures that exceed this threshold. For example, spotted tilapia, (Tilapia mariae), native to parts of Africa, prefer temperatures between 25 and $33{ }^{\circ} \mathrm{C}$, depending upon acclimation temperature, and have a critical thermal maxima of $37{ }^{\circ} \mathrm{C}$ [253]. Though tropical fishes can endure temperatures near to their temperature threshold, a slight $\left(1-2{ }^{\circ} \mathrm{C}\right)$ increase in regional temperatures may cause the daily temperature maxima to exceed these limits, mainly for populations that currently exist in thermally marginal habitats [253]. An increase in mean temperature may also increase metabolism of fish

Table 2 Impacts of droughts on livestock in African countries for the year 1981 to 1999

\begin{tabular}{llll}
\hline Date & Location & Livestock losses & Source \\
\hline $1981-1984$ & Botswana & $20 \%$ of national herd & {$[243]$} \\
$1982-1984$ & Niger & $62 \%$ of national cattle herd & {$[244,245]$} \\
$1983-1984$ & Ethiopia (Borana Plateau) & $45-90 \%$ of calves, 45\% of cows, 22\% of mature males & {$[246]$} \\
1991 & Northern Kenya & $28 \%$ of cattle; 18\% of sheep and goats & {$[247,248]$} \\
$1991-1993$ & Ethiopia (Borana) & $42 \%$ of cattle & {$[189,249]$} \\
1993 & Namibia & $22 \%$ of cattle; 41\% of goats and sheep & {$[250]$} \\
$1995-1997$ & Greater Horn of Africa (average of 9 pastoral & $20 \%$ of cattle; 20\% of sheep and goats & \\
$1995-1997$ & areas) & $46 \%$ of cattle; 41\% of sheep and goats & \\
$1998-1999$ & Southern Ethiopia & $62 \%$ of cattle & {$[247,251]$} \\
\hline
\end{tabular}


and other aquatic organisms [254]. For example, anoxic hypolimnia that serve as nutrient stores contain high concentrations of hydrogen sulfide. This chemical is a byproduct of anaerobic breakdown of organic substance and it is toxic to fish. For instance, recent changes in the limnology of Lake Victoria have also negatively affected its fishery [255].

Plant diseases and insect epidemics are controlled by climate and hence will be sensitive to $\mathrm{CC}$ to a large degree $[88,240]$. Beyond economic, and social impacts, the disease also affects food security and nutrition as well. Breeding crops for pest and disease resistance has been relatively effective under stable climatic conditions $[92,100,256,257]$. However, the range of several pathogens is limited by climate requirements for vegetating or over-summering. For example, higher winter temperatures of $-6{ }^{\circ} \mathrm{C}$ vs. $-10{ }^{\circ} \mathrm{C}$ increase the survival of overwintering rust fungi (Puccinia graminis) and increase subsequent disease on Festuca and Lolium [258]. Thus atmospheric $\mathrm{CO}_{2}$ reduces the ability of soybean to defend itself against bean leaf beetle resulting in increased beetle populations [259]. Biotic interactions, pest and disease pressure, competition, and successional dynamics and changes in symbiotic compositional interactions are also affected by CC too [260].

Wild foods are important to households that struggle to produce food or secure an income [261]. However, a change in the geographic distribution of wild foods resulting from changing rainfall and temperatures have an impact on the availability of food. Therefore, changes in climatic conditions have led to significant declines in the provision of wild foods by a variety of ecosystems, and further impacts can be expected as the world climate continues to change [262]. From the 5000 plant species examined in sub-Saharan African, 81 to $97 \%$ of the suitable habitats will decrease in size or shift owing to CC [263, 264]. In the year 2085,25 to $42 \%$ of the habitats are expected to be lost altogether. For example, over the next 40 years, the wild relatives of many crop species fall into the category of threatened species. Furthermore, up to $61 \%$ of peanut species, $12 \%$ of potato species, and $8 \%$ of cowpea species could become extinct within 50 years [265]. The threatened species include those with important genetic traits for agriculture and upon which some societies depend directly through wild harvesting. Therefore, $\mathrm{CC}$ will impact the ability of wild species to survive. Consequently, communities that use those plants as food and medicine are affected too.

$\mathrm{CC}$ increases the genetic erosion of landraces and threatening wild species, including crop wild relatives $[109,265]$. As a result, the existing varieties could be lost as farmers are replacing them with other landraces and improved varieties that are better adapted to the new conditions. For instance, Guinea sorghum varieties in the Sudanian zone of southern Mali showed that the range of varieties grown by families are heavily influenced by $\mathrm{CC}$, as the rainy season has shortened over the last 20 years [266]. Being centers for diverse landrace in CC prone regions aggravated the problem. However, adapting crop varieties to local ecological conditions can reduce the risk of CC [92, 267, 268]. Besides, the need for adapting germplasm is urgent and requires characterization, evaluation, and the availability of materials now housed in gene banks [269]. Since the beginning of the twentieth century, about $75 \%$ of the genetic diversity of agricultural crops has been lost [270, 271]. Therefore, all countries relying on crop genetic diversity that provides potential adaptation to environmental and climatic changes are challenged. On the other hand, crop wild relatives will play a crucial role in providing the genes and traits to help confront these challenges. Thus varieties and cultivation practices have permitted agriculture to withstand the moderate change in climate over the past 10,000 years $[257,265,272]$.

\section{Challenges and options of feeding the future in a changing climate and biodiversity loss}

Could global food security goals of the future be met in the face of CC and biodiversity loss is a big concern of twenty-first century [212, 273, 274]? Consequently, achieving food security and conserving biodiversity is among the most critical challenges of our time [257, 275, 276]. Currently $>1$ billion people are hungry and $>2$ billion are malnourished globally [63]. Furthermore, the world's population is expected to grow to nine billion by the year 2050 [277]. Thus there is a need for $70-100 \%$ more food [278]. Furthermore, developing countries will account for $93 \%$ and $85 \%$ of cereal and meat demand growth to 2050. Likewise, more than 30 million people in African currently lack access to safe water and adequate food [279]. Therefore, global food security will remain a worldwide concern for the coming years. Furthermore, flooding and desertification lead to loss of agricultural lands and biodiversity, poisoning of water supplies, and destruction of economic infrastructures thereby preventing buying and selling foods on the markets [280]. This will, in turn, resulted a decline in irrigation, rural infrastructure, and increasing water scarcity [48]. Likewise, crop yield and growth has slowed in the face of global environmental change and biotic threats [281]. Therefore, poor communities tend to have more limited adaptive capacities and are more dependent on climate-sensitive resources such as water and food supplies [280, 282]. CC is also a new challenge and crucial factor affecting food security and biodiversity loss in many regions $[109,257$, 272]. 
In the past, the primary solution to food shortages has been to bring more land into agriculture and to exploit new fish stocks [278]. However, recently land shortage and the competition for land from other human activities make this an increasingly unlikely and costly solution when protecting biodiversity and natural ecosystems are given higher priority [108, 212, 235, 283]. Moreover, the conventional model to achieve food security has been to convert wildlands to intensive commercial agricultural use [63] leading to the increased homogenization of natural landscapes. An immediate result of this model has been a drastic loss of wildlands, biodiversity, and ecosystem services [284]. Agricultural land which was productive in the past has been converted to urbanization, desertification, salinization, and soil erosion in recent decades [285]. Therefore, increasing yields need to translate biodiversity or more land spared for nature [286]. Thus if the current model of the commercialized monoculture is to be followed, feeding the global population is stated to require the conversion of yet more wildlands [287]. Consequently, a billion hectares of natural habitat will need to be converted to agricultural production, when the effects of CC on crop yields are taken into account [92, 288]. However, mitigating food waste could lessen the need for further land conversion and biodiversity loss [90].

The three major yield-enhancing strategies include researching to increase the harvest index, plant biomass, and stress tolerance [100, 289, 290]. Furthermore, breeding plants and animals for tolerance to drought, heat stress, salinity, and flooding will be more important [100, 257, 291]. In addition to conventional breeding, recent developments in nonconventional breeding, such as marker-assisted selection, cell, and tissue culture techniques, could be employed for crops in developing countries. Similarly, novel technologies must be established to quicken breeding via improved genotyping, and phenoltyping methods. This is vital to rise the accessible genetic diversity in breeding germplasm [292]. Furthermore, the use of indigenous and locally adapted plants and animals, the selection and multiplication of crop varieties that are resistant to adverse climatic conditions could bring a positive response [109]. Therefore, biodiversity loss and food security problems can be achieved by effective use of genetic resources and traditional ecological knowledge under the CC scenario. Furthermore, providing appropriate compensation for food-insecure people conserving biodiversity could guarantee a sustainable livelihood [293]. Besides new crop management systems are required that increase yields and reduce production costs by enhancing the efficiency of input application, increasing water use efficiency, and reducing greenhouse gas emissions. Consequently, effective and fruitful rice-based invention arrangements are crucial for economic development and improved the quality of life of the human population globally [294]. This is due to rice varieties exhibit enhanced nutritional value, require less water, produce high yields in drylands, minimize post-harvest losses, increased resistance to drought, and pests and increased tolerance to floods and salinity. For example, rice varieties with salinity tolerance have been used to expedite the recovery of production in areas damaged by the 2005 Asian tsunami [295].

Biodiversity provides an irreplaceable sources of food, new drugs, and harbor genetic variation which may have evolutionary importance for pest resistance, soil fertility, and pollination. Therefore, food production is dependent on biodiversity services [219, 290, 296]. However, once the genetic material is lost, no information on what role it may play in the future cannot obtain [273, 297]. Linking these challenges has created a narrative dominated by the notion of an inevitable trade-off between food production and biodiversity conservation. Well-known examples of frameworks that attempt to reduce such trade-offs include the concept of land sparing vs. land sharing [298]. Therefore, exploring typical relationships between social-ecological system characteristics and outcomes with respect to food security and biodiversity conservation is a must [299]. Moreover, both the need to provide food to local people, and pressure on biodiversity are particularly acute in the global food security and biodiversity conservation scenario. However, no global systematic assessments on either food security or biodiversity are available at the landscape scale. Therefore, the future rate of biodiversity loss must decline through wellplanned systems of protected areas [300]. Besides, biodiversity conservation strategies should involve deciding what to conserve and where to conserve. However, the manifestation of biodiversity at many organization levels in dynamic spatial patterns that are being highly scaledependent makes it a challenge. Regarding what to conserve, we can distinguish conservation planning based on habitat or ecosystem types [301]. Therefore, conservation may also extend to sub-species or distinctive populations and sustainable use of plant genetic resources.

"Biodiversity is supposed to be an accepted protection strategy to CC" [268, 302]. Such approaches may rely on a broader agricultural base integrated with diverse ecosystems. Therefore, using agrobiodiversity to mitigate environmental and climatic uncertainty is another option too [290, 303-305]. Furthermore, the integration of natural pest control and improving soil fertility resulted in yield increases by up to $80 \%$. Thus landscape complexity is vital for agroecological functions such as pest management, pollination, soil, and water quality improvement [306]. CC mitigation and adaptation using an ecosystem-based 
approaches is another way to increase food production. This creates synergies, increase resilience, and production efficiency. Furthermore, food security can be delayed by including the matrix of adjacent wildland, given the importance of landscape complexity for agroecological functions (pest management, pollination, soil, and water quality) [276]. In contrast, a trade-off between food security and biodiversity loss is related to a singular focus on built and financial capital in a given landscape [275]. Thus degradation land restoration, application of clean development mechanism (CDM), protection of watershed and coastal areas, preservation of mangroves and coastal fisheries, and biodiversity conservation can bring positive effect [307]. Therefore, achieving food security under a changing climate and biodiversity loss needs policy and investment reforms on (humans and water resources, research, rural infrastructure, and community-based biodiversity conservation) [308]. Likewise, risk minimization in marine, coastal, inland water and floodplain, forest, dry land, island, mountain, polar, and cultivated ecosystem is another option too [309, 310]. Moreover, research and dissemination of varieties and breeds capable of adapting to CC and providing food, fodder, energy, and cash incomes may address the issue [291]. Avoiding disruptions in food supplies due to changes in climate through more efficient water management could reduce the problem as well. Further, improved management of cultivated land, livestock and energy-efficient technologies are helpful [311]. Agro-ecology-based innovations, climate-smart agricultural practices, and resource-conserving productions that reduce farmers' dependence on external inputs, relying on existing potentials in plants and soil systems represents a different approach to meeting food security goals in the twenty-first century $[47,54$, $55,312]$. Shifts in agronomic practices and water management strategies, such as site-specific nutrient management, organic farming, use of irrigation, nutrient-dense crops, and short-duration crops are also another possibilities [46].

Sustainable forest management (SFM) which is targeted to preserve and enrich the economic, social, and environmental values of forests for the benefit of present and future generations is another option too [48]. SFM denotes to sustain the forest ecosystem and its functions, favoring socially or economically valuable species for the improved production of goods and services [313]. SFM includes adapting and planning for $\mathrm{CC}$, pest, and disease outbreak, managing forests, and woodlands to cope with new climatic conditions [314]. So that they contribute to flood prevention, and provide habitats and wildlife corridors for diverse flora and fauna. Furthermore, improving the management of biomass can make important contributions to developing nations where large numbers of poor life can solve food shortage [315]. At the household level, the poorest people use manure, twigs, and low-grade biomass for cooking [316]. As they move up the economic ladder, they switch to fuelwood, progressing through charcoal, kerosene, and gas to electricity, and integrating animals and simple tools into production processes. Therefore, forest conservation and management may bring a beneficial solution for $\mathrm{CC}$ mitigation, reductions of desertification and biodiversity loss, and enhance food production [216].

\section{Acclimatization, adaptation and mitigation measures of a changing climate}

Acclimatization is a powerful and effective adaptation strategy to live comfortably with a changing climate. While, adaptation refers to adjusting/accommodating to $\mathrm{CC}$ induced impacts, such as minimizing negative consequences and enhancing opportunities [317]. Furthermore, CC adaptation includes "initiatives and measures to reduce the vulnerability of natural and human systems against actual or expected CC effects" [48]. Besides, it is comprised of "adjustments in natural or human schemes in reply to the real or expected climatic stimuli and their effects" [201]. Furthermore, CC adaptation focuses on preparing for coping with and responding to the impacts of current and future CC [257, 268, 318]. Therefore, it intends to deliberate adjustments in natural or human systems and behaviors to reduce the risks of people's lives and livelihoods [201]. Adaptation responses are essentially planned or unplanned policy responses designed to increase the resiliency of our natural, socioeconomic, and built environments [319]. Planned adaptation to $\mathrm{CC}$ denotes actions undertaken to reduce the risks and capitalize on the opportunities associated with global CC [318]. However, adaptation is crucial at present because biodiversity and earth's ecosystems are being more vulnerable to a changing climate.

Mitigation of $\mathrm{CC}$ involves actions to reduce greenhouse gases (GHG) emissions and sequester carbon and develop choices that will lead to low emissions in the long term $[268,320]$. It is reported that $30 \%$ of the world's GHG emissions come from land-use change (deforestation) [65]. Likewise, Livestock production (animal digestion, feed production, and manure management), and forest cover loss contribute about $14.5 \%$ of GHG emissions. Therefore, half of the emissions globally are because of land clearing. Consequently, the future emission reduction scenarios should focus on improved feed systems, manure management strategies, efficient fertilizer use, deforestation reduction, and degraded land restoration [65]. Changes in land management and land use may also moderate local and regional climate through changes in albedo, evapotranspiration, soil moisture, 
and temperature $[60,80]$. Therefore, it is via landscape management approaches (diverse landscapes) that sustainable food production, biodiversity conservation, and CC mitigations across entire regions are maintained [53, 54]. Moreover, studies noted that options for mitigating GHG emission include improved crop and grazing land management, restoration of soils, and degraded lands [321]. However, mitigation is possible with improved water management, land-use change, agroforestry, and improved livestock management. Soil carbon sequestration has the greatest mitigation potential, with an estimated $89 \%$ contribution under adaptive management [322]. The development of new mitigation practices for livestock systems and fertilizer applications will be essential to prevent an increase in emissions from agriculture. Therefore, mitigation is the anthropogenic intervention to shrink the sinks of GHG [201]. Mitigation activities include reducing GHG emissions through the reduction of fossil fuel use, conservation of ecosystems, biodiversity, and increase in the rate of carbon uptake by ecosystems [323]. Depending on the design and implementation of strategies such as land use and forestry (afforestation, reforestation, and land management practices, and use of renewable energy sources (biomass, wind, and solar power)) mitigation strategies can have positive, neutral, or negative impacts [324]. However, these strategies may lead to loss of biodiversity by substituting rapidly growing diversified forests for monoculture plantations for growing biofuel demands [325]. Another prominent mitigation activity for the reduction of fossil fuel use is putting taxes on emissions [324]. Furthermore, tapping tradable permits, implementing laws and regulations to restrict the use of fossil fuel can be more effective [201]. Lawful provisions of voluntary agreements, technology, and performance standards, support of energy efficiency improvement, and road pricing are other mitigation strategies [326]. Therefore, mitigation policy measures could reduce the atmospheric concentration of GHG to levels that do not dangerously interfere with the climatic conditions [320]. Management of water resources, land rehabilitation, and application of biotechnology are also considered as effective adaptation measures for CC [53]. Consequently, depending on the intended outcomes, mitigation approaches can seek to either maintain the persistence of current conditions or facilitate transitions to alternative states [318].

\section{Conclusions}

In general, this review is intended to provide validated and up-to-date scientific information on the impacts of $\mathrm{CC}$ on global biodiversity and food security. Thus it is limited to the aims of global CC mitigation and adaptation measures in view of multidimensional aspects of biodiversity, biodiversity-food interactions, and means of meeting global food security under CC and biodiversity loss scenarios.

Although biodiversity provides food for all life forms and used as primary health care for more than $60-80 \%$ of the world's human population, it has been affected by human activities and $\mathrm{CC}$. Thus, $\mathrm{CC}$ through the increased temperatures by $0.798{ }^{\circ} \mathrm{C}$ and concentration of $\mathrm{CO}_{2}$ level from 280 to $379 \mathrm{ppm}$ would have an impact on timing seasons of flora and fauna. Accordingly, species, ecosystem composition, and function have been affected both directly and indirectly. Thus species have been shown a modification in their morphology, physiology, behavior, and they are forced to migrate due to changes in climatic variables globally. Furthermore, CC has also the potential to reduce species that are unable to track the climate to which they are currently adapted and resulted in extinction risk. Consequently, the recent rates of species extinction are estimated to be 100 to 1000 times faster. However, changes in climatic variables assert strong selective pressure on natural populations. For example, species that have the capability to keep up with climate shifts may survive while others that cannot respond will suffer.

A changing climate is responsible for dramatic shifts in the range, and geographical distributions of species and ecosystems. For example, the dissemination of species have recently shifted to higher elevations at a rate of $11.0 \mathrm{~m}$ per decade, and to higher latitudes at a rate of $16.9 \mathrm{~km}$ per decade. These rates are approximately two to three times faster than previously reported. Likewise, changes in plants' range render many species are unable to follow the climate to which they are adapted. In contrast, climate change-driven species' range shift responses may depend on species types, ecosystem, and altitude. Therefore, adaptation to future climates may require the simultaneous evolution of a number of different traits. However, species range shift is not only because of $\mathrm{CC}$, but also due to intensified grazing, land use change, disturbance, and fire regimes.

Long-term changes in weather conditions have severe impacts on food security, availability, accessibility, and utilization. Similarly, changes in mean temperatures and rainfall will affect the suitability of land for crops, pasture, and productivity of marine resources. It will also increases the incidence of pests and diseases; loss of biodiversity, a decline of ecosystem functioning; reduce the availability of water for crop, livestock, and inland fish production. CC affects food security for communities that depend on rain-fed agriculture. In this regard, $\mathrm{CC}$ is expected to reduce global cereal production by $1-7 \%$ in 2060. Besides, it leads to 5-170 million additional people being at risk of hunger by 2080 . Furthermore, $>1$ 
billion people are hungry and $>2$ billion are malnourished globally. Consequently, a billion hectares of natural habitat will need to be converted to agricultural production, when the effects of $\mathrm{CC}$ on crop yields are taken into account. Consequently, achieving food security and conserving biodiversity under $\mathrm{CC}$ scenario are among the most critical challenges of the 21th century. Therefore, unless policy, land use, and investment reforms, achieving food security under a changing climate and biodiversity loss is hard to achieve. However, alleviating food waste, the restoration of land degradation, and applying $\mathrm{CC}$ mitigation policy measures could bring a positive effect. Therefore, the future research and innovations should focus on exploiting the existing opportunities and available resources on raising food production, CC mitigation measures, and biodiversity conservation strategies $[46,327]$.

\section{Recommendations on climate change adaption, biodiversity loss, and food security}

Re-searching and releasing high-yielding, biotic and abiotic stress resistant, and suitable varieties across agro-ecologies are recommended as a major adaptation and mitigations strategies for CC impacts globally [46]. Accordingly, varieties that could withstand both biotic and abiotic stresses and CC must be accessible at a larger scale with adequate financial and policy support. Besides, using cultivation methods that increase water productivity via irrigation is needed. Moreover, further research on species ecological requirements, ecosystem-based CC mitigation options, species adaptation trails, and emphasis on the symbiotic relationships between plants and soil microbes are crucial [328]. Researching for bio-fertilizers, wild edible plants [329], microbial inoculants, improved technologies that are less dependent on scarcer resources such as arable land, and water is suggested [312]. Likewise, focusing to develop CC resilient irrigation structures or systems and wide us of bio and alternative energy resources are needed. Furthermore, improving natural resources management and use practices, maintaining agro-biodiversity, and implementation of climate-smart agriculture are a must. Besides, applying biodiversity conservation strategies and performing land restoration programs at a larger large scale are suggested. Therefore, future research and development should focus on the researching and innovation of climate-resilient technologies, alternative and carbon neutral energy sources, use of bio-energies, and wild food sources.

\section{Abbreviations}

FAO: Food and Agriculture organization of the United Nations; GHG: Greenhouse gases; IPCC: Intergovernmental Panel on Climate Change; IUCN:
International Union for Conservation of Nature; Ppm: Parts per million; WMO: World Meteorological Organization.

\section{Acknowledgements}

Not applicable.

Authors' contributions

The author read and approved the final manuscript.

Funding

Not applicable.

Availability of data and materials

Not applicable.

\section{Declarations}

Ethics approval and consent to participate

Not applicable.

\section{Consent for publication}

Not applicable.

Competing interests

Not applicable.

Received: 19 November 2020 Accepted: 15 June 2021

Published online: 06 September 2021

References

1. WMO. WMO. Glob. Ozone Res. Monit. Proj. Geneva; 2006.

2. Kotir JH. Climate change and variability in Sub-Saharan Africa : a review of current and future trends and impacts on agriculture and food security. Env Dev Sustain. 2011;13:587-605.

3. IPCC. CC IPCC Asst.PDF. 2ND ed. Houghton JT, G.J.Jenkins, Ephraums JJ, editors. NEW YORK: Cambridge University Press; 1995.

4. Penuelas J, Janssens IA, Ciais P, Obersteiner M, Sardans J. Anthropogenic global shifts in biospheric $\mathrm{N}$ and $\mathrm{P}$ concentrations and ratios and their impacts on biodiversity, ecosystem productivity, food security, and human health. Glob Chang Biol. 2020;26:1962-85.

5. Jones PD. The evolution of climate over the last millennium. AAAS. 2001;292:662-7.

6. Dawson TP, Perryman AH, Osborne TM. Modelling impacts of climate change on global food security. Clim Change. 2016;134:429-40.

7. Dullinger S, Dirnböck T, Grabherr G. Modelling climate change-driven treeline shifts: relative effects of temperature increase, dispersal and invasibility. J Ecol. 2004;92:241-52.

8. Morton JF. The impact of climate change on smallholder and subsistence agriculture. Proc Natl Acad Sci USA. 2007;104:19680-5.

9. Vermeulen SJ, Campbell BM, Ingram JSI. Climate change and food systems. Annu Rev Environ Resour. 2012;37:195-222.

10. Reidsma P, Ewert F, Lansink AOLR. Adaptation to climate change and climate variability in European agriculture: the importance of farm level responses. Eur J Agron. 2010;32:91-102.

11. Wiebe K, Robinson S, Cattaneo A. Climate change, agriculture and food security. Sustain Food Agric. 2019. https://doi.org/10.1016/B978-0-12812134-4.00004-2.

12. Davis MB, Shaw RG. Range shifts and adaptive responses to quaternary climate change. Science. 2001;292:673-9.

13. Walther G. Plants in a warmer world. Perspect Plant Ecol Evol Syst. 2003;6:169-85.

14. Lloyd AH, Armbruster WS, Edwards ME. Ecology of a steppe-tundra gradient in interior Alaska. J Veg Sci. 1994;5:897-912.

15. Kullman $L$. Rapid recent range-margin rise of tree and shrub species in the Swedish Scandes. J Ecol. 2002;90:68-77.

16. Grabherr G, Gottfried M, Pauli H. Climate effects on mountain plants. Nature. 1994;369:448. 
17. Penuelas J, Boada M. A global change-induced biome shift in the Montseny mountains (NE Spain). Glob Chang Biol. 2003;9:131-40.

18. Van Der PWH. Climate Change, Interactions, and Species 'Range Shifts. Annu Rev Ecol Evol Syst. 2012;43:365-83.

19. Woodward F. Stomatal numbers are sensitive to increases in $\mathrm{CO} 2$ from pre-industrial levels. Nature. 1987;327:617-8.

20. Kang Y, Khan S, Ma X. Climate change impacts on crop yield, crop wate productivity and food security - A review. Prog Nat Sci. 2009;19:166574. https://doi.org/10.1016/j.pnsc.2009.08.001.

21. Crawfor RMM. Trees by the sea: advantages and disadvantages of oceanic climates. Biol Environ. St Andrews: Royal Irish Academy; 2005. p. 129-39.

22. Thomas CD, Cameron A, Green RE, Bakkenes M, Beaumont LJ, Collingham YC, et al. Letter to nature: extinction risk from climate change. Nature. 2004;427:145-8.

23. Huntley B. How plants respond to climate change: migration rates, individualism and the consequences for plant communities. Ann Bot. 1991;67:15-22.

24. BRADSHAW AD, MCNEILLY T. Brashaw and McNeilly 1991.pdf. Ann Bot. 1991;67:5-14.

25. Etterson JR. Evolutionary potential of Chamaecrista Fasciculata in relation to climate change. Ii. Genetic architecture of three populations reciprocally planted along an environmental gradient in the Great Plains. Evolution. 2004:58:1459-71.

26. Mooney H, Larigauderie A, Cesario M, Elmquist T, Hoegh-guldberg O, Lavorel S, et al. Biodiversity, climate change, and ecosystem services. Curr Opin Environ Sustain. 2009:1:46-54.

27. Heller NE, Zavaleta ES. Biodiversity management in the face of climate change: a review of 22 years of recommendations. Biol Conserv. 2008;142:14-32. https://doi.org/10.1016/j.biocon.2008.10.006.

28. Bhattarai U. Impacts of climate change on biodiversity and ecosystem services: direction for future research. Hydro Nepal. 2012;10:41-8.

29. Lavergne S, Mouquet N, Thuiller W, Ronce O. Biodiversity and climate change: Integrating evolutionary and ecological responses of species and communities. Annu Rev Ecol Evol Syst. 2010:41:321-50.

30. Iverson JB, Smith GR. Reproductive ecology of the painted turtle (Chrysemys picta) in the Nebraska Sandhills and across its range. Copeia. 1993:110:1689-99.

31. Sheridan JA, Bickford D. Shrinking body size as an ecological response to climate change. Nat Clim Chang. 2011;1:401-6. https://doi.org/10. 1038/nclimate1259.

32. IPCC. IPCC special report on Carbon dioxide capture and storage structure of the intergovernmental panel on climate change ( IPCC). Cambridge Univ. Press. Cambridge, UK. Tokyo; 2006.

33. Kulakowski D, Bebi P, Rixen C. The interacting effects of land use change, climate change and suppression of natural disturbances on landscape forest structure in the Swiss Alps. Oikos. 2011;120:216-25.

34. Anderson PK, Cunningham AA, Patel NG, Morales FJ, Epstein PR, Daszak P. Emerging infectious diseases of plants: pathogen pollution, climate change and agrotechnology drivers. Trends Ecol Evol. 2004;19:535-44

35. Vincent K, Tanner T, Devereux S. Climate Change, Food Security and Disaster Risk Management Issues paper for the Expert Meeting on Climate Change and Disaster Risk Management, Summary This issues paper serves as input to an expert meeting on climate change and disaster risk reduction t. Rome; 2008.

36. Edame GE, Anam BE, Fonta WM, Duru E. Climate Change, Food Security and Agricultural Productivity in Africa: Issues and Policy Directions ', International ... Climate Change, Food Security and Agricultural Productivity in Africa : Issues and policy directions Cross River State, Nigeria. Int J Humanit Soc Sci. 2011;1:205-23.

37. Brown ME, Carr ER, Grace KL, Wiebe K, Funk CC, Attavanich W, et al. Do markets and trade help or hurt the global food system adapt to climate change? Food Policy. 2017;68:154-9. https://doi.org/10.1016/j.foodpol. 2017.02.004.

38. Fuhrer J, Booker F. Ecological issues related to ozone: agricultural issues. Environ Int. 2003:29:141-54.

39. Amthor JS. Effects of atmospheric $\mathrm{CO} 2$ concentration on wheat yield: review of results from experiments using various approaches to control CO2 concentration. F Crop Res. 2001;73:1-34.

40. IPCC. Summary for Policymakers. In Climate Change 2007: impacts, adaptation and vulnerability. Contribution of Working Group II to the
Fourth Assessment Report of the Intergovernmental Panel on Climate Change. Nairobi; 2007.

41. Banik D. Achieving food security in a sustainable development era. Food Ethics. 2019;4:117-21.

42. Kroll C, Warchold A, Pradhan P. Sustainable Development Goals (SDGs): are we successful in turning trade-offs into synergies? Palgrave Commun. 2019;5:1-11. https://doi.org/10.1057/s41599-019-0335-5.

43. Tumushabe JT. Climate change, food security and sustainable development in Africa. In: Oloruntoba SO, Falola T, editors. Clim Chang Food Secur Sustain Dev Africa. 1st ed. New York: Palgrave Macmillan; 2017. p. 853-68.

44. Gomez-Echeverri L. Climate and development: enhancing impact through stronger linkages in the implementation of the Paris Agreement and the Sustainable Development Goals (SDGs). Philos Trans R Soc A Math Phys Eng Sci. 2018;376:20160444.

45. Filho L, Tripathi W, Guerra SA, Garriga J, Lovren RO, Willats V. Using the sustainable development goals towards a better understanding of sustainability challenges. Int J Sustain Dev World Ecology. 2018;26:179-90.

46. Chhogyel N, Kumar L. Climate change and potential impacts on agriculture in Bhutan: a discussion of pertinent issues. Agric Food Secur. 2018;7:1-13. https://doi.org/10.1186/s40066-018-0229-6.

47. Steenwerth KL, Hodson AK, Bloom AJ, Carter MR, Cattaneo A, Chartres CJ, et al. Climate-smart agriculture global research agenda : scientific basis for action. Agric Food Secur. 2014;3:1-39.

48. Meybeck A, Laval E, Levesque R, Parent G. Food security and nutrition in the age of climate change. In: Meybeck A, Laval E, Lévesque R, Paren G, editors. Food Secur Nutr Age Clim Chang. Québec City: FAO; 2018. p. 132.

49. Fischer J, Abson DJ, Bergsten A, French Collier N, Dorresteijn I, Hanspach $\mathrm{J}$, et al. Reframing the food-biodiversity challenge. Trends Ecol Evol. 2017;32:335-45. https://doi.org/10.1016/j.tree.2017.02.009.

50. Turney C, Ausseil AG, Broadhurst L. Urgent need for an integrated policy framework for biodiversity loss and climate change. Nat Ecol Evol. 2020;4:996. https://doi.org/10.1038/s41559-020-1242-2.

51. Weiskopf SR, Rubenstein MA, Crozier LG, Gaichas S, Griffis R, Halofsky $J E$, et al. Climate change effects on biodiversity, ecosystems, ecosystem services, and natural resource management in the United States. Sci Total Environ. 2020;733:137782

52. Ripple WJ, Smith P, Haberl H, Montzka SA, McAlpine C, Boucher DH. Ruminants, climate change and climate policy. Nat Clim Chang. 2014;4:2-5. https://doi.org/10.1038/nclimate2081.

53. El-beltagy A, Madkour M. Impact of climate change on arid lands agriculture. Agric Food Secur. 2012;3:1-12.

54. Scherr SJ, Shames S, Friedman R. From climate-smart agriculture to climate-smart landscapes. Agric Food Secur. 2012;1:1-15.

55. Zougmoré R, Partey $S$, Ouédraogo M, Omitoyin B, Thomas T, Ayantunde A, et al. Toward climate - smart agriculture in West Africa : a review of climate change impacts, adaptation strategies and policy developments for the livestock, fishery and crop production sectors. Agric Food Secur BioMed Central. 2016;5:1-16.

56. Tamiru D, Belachew T. The association of food insecurity and school absenteeism: systematic review. Agric Food Secur. 2017;6:4-7.

57. Palm CA, Smukler SM, Sullivan CC, Mutuo PK, Nyadzi GI, Walsh MG. Identifying potential synergies and trade-offs for meeting food security and climate change objectives in sub-Saharan Africa. PNAS. 2010;107:19661-6.

58. Wheeler T, Braun JV. Climate change impacts on global food security. Science. 2013;341:508-12.

59. Lobell DB, Burke MB, Tebaldi C, Mastrandrea D, et al. Prioritizing climate change adaptation needs for food security in 2030. Science. 2008;319:607-10.

60. Desjardins RL, Sivakumar MVK, de Kimpe C. The contribution of agriculture to the state of climate: workshop summary and recommendations. Agric For Meteorol. 2007;142:314-24.

61. Sala OE, Chapin FS III, Armesto JJ, Berlow E, Janine B, et al. Global biodiversity scenarios for the year 2100. Science. 2000;287:1770-4.

62. Ghimire B, Sharma S. Nutritional security and biodiversity conservation with Sea Buckthorn (Hippophae Spp. L.): an underutilized species of Himalayan. Int J Agric Biosyst Eng. 2018;3:42-5.

63. Chappell MJ, LaValle LA. Food security and biodiversity: can we have both? An agroecological analysis. Agric Human Values. 2011;28:3-26. 
64. Trew BT, Maclean IMD. Vulnerability of global biodiversity hotspots to climate change. Glob Ecol Biogeogr. 2021;30:768-83.

65. Smith P, Martino D, Cai Z, Gwary D, Janzen H, Kumar P, et al. Policy and technological constraints to implementation of greenhouse gas mitigation options in agriculture. Agric Ecosyst Environ. 2007;1 18:6-28.

66. IUCN. 50 Years of Working for Protected Areas-A brief history of IUCN World Commission on Protected Areas. http://cmsdata.iucn.org/downl oads/history_wcpa_15july_web_version_1.pdf. Gland; 2010.

67. Eldredge N. Life on Earth: An Encyclopedia of Biodiversity, Ecology, and Evolution. 2nd ed. Eldredge N, editor. Califormia: ABC-CLIO; 2002.

68. Heywood VH. Global biodiversity assessment. Trends Ecol Evol. 1997;12:39-40.

69. Naa S, Aryee D, Adjei DO, Amponsah RO, Skinner B, Sowatey E, et al. Sustainable genomic research for food security in sub - Saharan Africa. Agric Food Secur. 2021. https://doi.org/10.1186/s40066-021-00287-9.

70. Tscharntke T, Klein AM, Kruess A, Steffan-Dewenter I, Thies C. Landscape perspectives on agricultural intensification and biodiversity - Ecosystem service management. Ecol Lett. 2005;8:857-74.

71. Haines-Young R, Potschin M. The links between biodiversity, ecosystem services and human well-being. 2nd ed. Raffaelli D, Frid C, editors. J. Geophys. Res. Cambridge: Cambridge University Press; 1982.

72. Mojzsis SJ, Arrhenius G, McKeegan KD, Harrison TM, Nutman AP, Friend CRL. Evidence for life on earth before 3,800 million years ago. Nature. 1996;384:55-9.

73. Redford K. Human influence on biodiversity. 1st ed. V.H. Hewood, editor. Cambridge: Cambridge University Press; 1995.

74. Vitousek PM, Mooney HA, Lubchenco J, Melillo JM. Human domination of earth's ecosystems. Science. 1997;297:494-9.

75. Foley JA, Foley JA, Defries R, Asner GP, Barford C, Bonan G, et al. Global consequences of land use. Science. 2009;570:570-4.

76. El Mujtar V, Muñoz N, Prack M, Cormick B, Pulleman M, Tittonell P. Role and management of soil biodiversity for food security and nutrition; where do we stand? Glob Food Sec. 2019;20:132-44. https://doi.org/10. 1016/j.gfs.2019.01.007.

77. Rutten M, Van Dijk M, Van Rooij W, Hilderink H. Land use dynamics, climate change, and food security in Vietnam: a global-to-local modeling approach. World Dev. 2014;59:29-46. https://doi.org/10.1016/j.world dev.2014.01.020.

78. Pilling D, Bélanger J, Hoffmann I. Declining biodiversity for food and agriculture needs urgent global action. Nat Food. 2020;1:144-7.

79. Branca G, Lipper L, McCarthy N, Jolejole MC. Food security, climate change, and sustainable land management. A review. Agron Sustain Dev. 2013;33:635-50.

80. Webb NP, Marshall NA, Stringer LC, Reed MS, Chappell AHJ. Land degradation and climate change: building climate resilience in agriculture. Front Ecol Environ. 2018;15:450-9.

81. Hens L. Causes of biodiversity loss : a human ecological analysis. Mech Econ Regul. 2015;1:420-50.

82. Lande R. Anthropogenic, ecological and genetic factors in extinction and conservation. Res Popul Ecol. 1998;40:259-69.

83. Hunde D. Human Influence and Threat to Biodiversity and Sustainable Living. Ethiop J Educ Sci. 2008;3.

84. Wilson BEO, Academy N, Pdf T, Press NA, Press NA, Academy N, et al. BIODIVERSITY. 2nd ed. E.O.Wilson, M.Pete F, editors. Washington: NATIONAL ACADEMY PRESS; 1988.

85. Tansey G. The Future Control of Food; The Future Control of Food A guide to international negotaiations and rules on intellectual property, biodivesity and food security. 1st ed. Tansey G, Rajotte T, editors. Futur. Control Food. Routledge: earthscan; 2012.

86. Sunderland TCH. Food security: why is biodiversity important? Int For Rev. 2011;13:265-74.

87. Cotter J, Tirado R. Food security and climate change: the answer is biodiversity. Amsterdam: Greenpeace Int; 2008. p. 2-7.

88. Chakraborty S, Newton AC. Climate change, plant diseases and food security: an overview. Plant Pathol. 2011;60:2-14.

89. Caliman A, Pires AF, Esteves FA, Bozelli RL, Farjalla VF. The prominence of and biases in biodiversity and ecosystem functioning research. Biodivers Conserv. 2010;19:651-64.

90. Scherr SJ, McNeely JA. Biodiversity conservation and agricultural sustainability: towards a new paradigm of "ecoagriculture" landscapes. Philos Trans R Soc B Biol Sci. 2008:363:477-94.
91. Steffan-Dewenter I, Potts SG, Packer L, Ghazoul J. Pollinator diversity and crop pollination services are at risk [3] (multiple letters). Trends Ecol Evol. 2005;20:651-2.

92. Di Falco S, Chavas JP. On crop biodiversity, risk exposure, and food security in the highlands of Ethiopia. Am J Agric Econ. 2009;91:599-611.

93. Ekroos J, Heliölä J, Kuussaari M. Homogenization of lepidopteran communities in intensively cultivated agricultural landscapes. J Appl Ecol. 2010;47:459-67.

94. Milner-Gulland EJ, Bennett EL, Abernethy K, Bakarr M, Bennett E, Bodmer R, et al. Wild meat: The bigger picture. Trends Ecol Evol. 2003;18:351-7.

95. Chivian E. Biodiversity: Its Importance to Human Health. Heal. (San Fr. Harvard; 2002. Report No.: 0410093.

96. Herndon CN, Butler RA. Significance of biodiversity to health. Biotropica. 2010;42:558-60.

97. Keesing F, Belden LK, Daszak P, Dobson A, Harvell CD, Holt RD, et al. Impacts of biodiversity on the emergence and transmission of infectious diseases. Nature. 2010;468:647-52.

98. Meyer RS, Duval AE, Jensen HR. Patterns and processes in crop domestication: an historical review and quantitative analysis of 203 global food crops. New Phytol. 2012;196:29-48.

99. Diamond J. Evolution, consequences and future of plant and animal domestication. Nature. 2002;418:700-7.

100. Singh R. Integration and commercialization of local varieties under sub-optimal environments for food security, promoting sustainable agriculture and agro-biodiversity conservation. MOJ Ecol Environ Sci. 2018:3:66-7.

101. Pimentel D, Wilson C, McCullum C, Rachel H, Huang R, Paulette, et al. Economic and Environmental Benefits of Biodiversity. Bioscience. 1997:47:747-57.

102. Tuxill J. Appreciating the Benefits of Plant Biodiversity [Internet]. State World 1999 A \{W\}orldwatch \{\}\}nstitute Rep. Prog. Towar. a Sustain. Soc. Rome; 1999. Available from: http://isbndb.com/d/book/state_of_the_ world_1999.html

103. Mathur PK, Lehmkuhl JF, Sawarka VB. Management of Forests in India for Biological Diversity and Forest Productivity A New Perspective. Dehra; 2002.

104. Kumar A, Marcot BG, Saxena A. Tree species diversity and distribution patterns in tropical forests of Garo Hills. Curr Sci. 2006;91:1370-81.

105. Hornborg A. Not just minor forest products: The economic rationale for the consumption of wild food plants by subsistence farmers. Ecol Econ. 2006:59:74-81.

106. Ros-Tonen MAF, Wiersum KF. The scope for improving rural livelihoods through non-timber forest products: an evolving research agenda. For Trees Livelihoods. 2005;15:129-48.

107. Ten Kate K, Laird SA. Biodiversity and business: Coming to terms with the "grand bargain." Int Aff. 2000;76:241-64.

108. Scherer L, Svenning JC, Huang J, Seymour CL, Sandel B, Mueller N, et al. Global priorities of environmental issues to combat food insecurity and biodiversity loss. Sci Total Environ. 2020;730:1-9. https://doi.org/10. 1016/j.scitotenv.2020.139096.

109. Jarvis A, Upadhyaya H, Gowda C, Aggarwa P, Fujisaka S, Anderson B. Climate Change and its Effect on Conservation and Use of Plant Genetic Resources for Food and Agriculture and Associated Biodiversity for Food Security. Rome; 2008.

110. Mellouki A, Talukdar PK, Mills J, Solomon S, Ravishankara AR.Atmospheric lifetimes and ozone depletion potentials of methyl bromide measured $\because$.' The accuracy of units coefficient at any temperature $T, k(T)-A x \exp [(-E / k) / T$ ] . Figure plots $k 2$ ( on a log vs. 1000/T .x f ( 298 ). Uncertainty at tempera. Geophys Res Lett. 1992;19:2059-62.

111. Cloern JE, Abreu PC, Carstensen J, Chauvaud L, Elmgren R, Grall J, et al. Human activities and climate variability drive fast-paced change across the world's estuarine-coastal ecosystems. Glob Chang Biol. 2016;22:513-29.

112. O'Gorman PA, Schneider T. The physical basis for increases in precipitation extremes in simulations of 21 st-century climate change. Proc Natl Acad Sci U S A. 2009;106:14773-7.

113. Martinez LH. Post industrial revolution human activity and climate change: Why The United States must implement mandatory limits on industrial greenhouse gas emmissions. J L Use Environ Law. 2005;20:403-21. 
114. Shaviv NJ, Veizer J. Celestial driver of Phanerozoic climate? GSA Today. 2003;13:4-10

115. Cronin TM. Paleoclimates: Understanding Climate Change Past and Present. 2nd ed. Cronin TM, editor. New York: Columbia University Press; 2009.

116. Jain PC. Climate change greenhouse effect and climate change: scientific basis and overview. Renew Energy. 1993;3:403-20.

117. Shindell D, Smith CJ. Climate and air-quality benefits of a realistic phase-out of fossil fuels. Nature. 2019;573:408-11.

118. Sánchez-Arcilla A, Mösso C, Sierra JP, Mestres M, Harzallah A, Senouci M, et al. Climatic drivers of potential hazards in Mediterranean coasts. Reg Env Chang. 2011;2100:617-36.

119. Linderholm HW. Growing season changes in the last century. Agric For Meteorol. 2006;137:1-14.

120. Reid H, Swiderska K. Biodiversity, climate change and poverty: an exploration of the linkages. Int Inst Environ Dev. 2008;12.

121. UNEP. Global Environment Outlook GEO-4: Environment for Development. Nairobi; 2007

122. Brierley AS, Kingsford MJ. Impacts of climate change on marine organisms and ecosystems review. Curr Biol. 2009;19:R602-14. https://doi. org/10.1016/j.cub.2009.05.046.

123. Regan HM, Lupia R, Drinnan AN, Burgman MA. The currency and tempo of extinction. Am Nat. 2001;157:1-10.

124. Parker WC, Courtillot V, McClinton J. Evolutionary Catastrophes: The Science of Mass Extinction. 1st ed. Fayard, editor. Palaios. Port Melbourn: Cambridge University Press; 2000.

125. Pimm SL, Russell GJ, Gittleman JL, Brooks TM. The future of biodiversity. Science. 1995;269:347-50.

126. Roy DB, Sparks TH. Phenology of British butterflies and climate change. Glob Chang Biol. 2000;6:407-16.

127. Malcolm JR, Liu C, Neilson RP, Hansen L, Hannah L. Global warming and extinctions of endemic species from biodiversity hotspots. Conserv Biol. 2006;20:538-48.

128. Poole JH. Mate guarding, reproductive success and female choice in African elephants. Anim Behav. 1989:37:842-9.

129. Thirgood S, Mosser A, Tham S, Hopcraft G, Mwangomo E, Mlengeya T, et al. Can parks protect migratory ungulates? The case of the Serengeti wildebeest. Anim Conserv. 2004;7:113-20.

130. Fitchett JM, Grab SW, Thompson DI. Plant phenology and climate change: Progress in methodological approaches and application. Prog Phys Geogr. 2015;39:460-82.

131. Vanacker V, Linderman M, Lupo F, Flasse S, Lambin E. Impact of short-term rainfall fluctuation on interannual land cover change in subSaharan Africa. Glob Ecol Biogeogr. 2005;14:123-35.

132. Bonkoungou EG. Biodiversity in drylands: challenges and opportunities for conservation and sustainable use. Zambia; 2001.

133. Chidumayo EN. Effects of climate on the growth of exotic and indigenous trees in central Zambia. J Biogeogr. 2005;32:111-20.

134. Hély C, Bremond L, Alleaume S, Smith B, Sykes MT, Guiot J. Sensitivity of African biomes to changes in the precipitation regime. Glob Ecol Biogeogr. 2006;15:258-70

135. Hillerislambers J, Harsch MA, Ettinger AK, Ford KR. How will biotic interactions influence climate change - induced range shifts? Ann NY Acad Sci. 2013;97:112-25.

136. Parmesan C, Yohe G. A globally coherent fingerprint of climate change impacts across natural systems. Nature. 2003;421:37-42.

137. Thuiller W. Patterns and uncertainties of species' range shifts under climate change. Glob Chang Biol. 2004;10:2020-7.

138. Colwell RK, Brehm G, Cardelús CL, Gilman AC, Longino JT. Global warming, elevational range shifts, and lowland biotic attrition in the Wet Tropics. Science. 2008;322:258-61.

139. Telwala Y, Brook BW, Manish K, Pandit MK. Climate-induced elevational range shifts and increase in plant species richness in a Himalayan biodiversity epicentre. PLOS ONE. 2013;8:e57103.

140. Chen I, Hill JK, Ohlemüller R, Roy DB, Thomas CD. Rapid range shifts of species of climate warming. Science. 2011;333:1024-7.

141. Samways MJ, Osborn R, Hastings H, Invertebrate VH. Global climate change and accuracy of prediction of species ' geographical ranges: establishment success of introduced ladybirds (Coccinellidae, Chilocorus spp.) worldwide. J Biogeogr. 1999;26:795-812.
142. Pearson RG, Dawson TP. Predicting the impacts of climate change on the distribution of species: are bioclimate envelope models useful ? Glob Ecol Biogeogr. 2003;12:361-71.

143. Parmesan C, Ryrholm N, Stefanescu C, Hill JK, Thomas CD, Descimon H, et al. Poleward shifts in geographical ranges of butterfly species associated with regional warming. Nature. 1999;399:579-83.

144. Erasmus BFN, Jaarsveld ASVAN, Chown SL. Vulnerability of South African animal taxa to climate change. Glob Chang Biol. 2002;8:679-93.

145. Cannone N, Sgorbati S, Guglielmin M. Unexpected impacts of climate change on alpine vegetation. Front Ecol Env. 2007;5:360-4.

146. Lenoir J, Ge J, Guisan A, Vittoz P, Wohlgemuth T, Zimmermann NE, et al. Going against the flow: potential mechanisms for unexpected downslope range shifts in a warming climate. Ecography (Cop). 2010;2005:295-303

147. ROUX PC. I e, MCGEOCH MA. Rapid range expansion and community reorganization in response to warming. Glob Chang Biol. 2008;14:2950-62.

148. Crimmins SM, Dobrowski SZ, Greenberg AJ, John T, et al. Changes in climatic water balance drive downhill shifts in plant species' optimum elevations. Science. 2011;331:324-7.

149. Kardol P, Bezemer TM, van der Putten WH. Temporal variation in plant soil feedback controls succession. Ecol Lett. 2006:9:1080-8.

150. Walther G, Post E, Convey P, Menzel A, Parmesan C, Beebee TJC, et al. Ecological responses to recent climate change. Nature. 2002:416:389-95.

151. Ozinga WA, Römermann C, Bekker RM, Prinzing A, Tamis WLM, Joop HJ, et al. Dispersal failure contributes to plant losses in NW Europe. Ecol Lett. 2009;12:66-74

152. Warren MS, Hill JK, Thomas AJ, Asher J, Fox R, et al. Rapid responses of British butterflies to opposing forces of climate and habit change. Nature. 2001:414:65-9. https://doi.org/10.1038/35102054.

153. Monroy F, van der Putten WH, Yergeau E, Mortimer SR, Duyts H, Bezemer TM. Community patterns of soil bacteria and nematodes in relation to geographic distance. Soil Biol Biochem. 2012;45:1-7. https://doi.org/ 10.1016/j.soilbio.2011.10.006.

154. Van Der Putten WH. Climate change, aboveground-belowground interactions, and species' range shifts. Annu Rev Ecol Evol Syst. 2012:43:365-83.

155. Bertrand R, Lenoir J, Piedallu C, Dillon GR, De Ruffray P, Vidal C, et al. Changes in plant community composition lag behind climate warming in lowland forests. Nature. 2011;479:517-20.

156. Leithead MD, Anand M, Silva LCR. Northward migrating trees establish in treefall gaps at the northern limit of the temperate-boreal ecotone, Ontario. Canada Oecologia. 2010;164:1095-106.

157. Bush MB. Distributional change and conservation on the Andean flank: a palaeoecological perspective. Glob Ecol Biogeogr. 2002;11:463-73.

158. Erasmus BFN, Van Jaarsveld AS, Chown SL, Kshatriya M, Wessels KJ. Vulnerability of South African animal taxa to climate change. Glob Chang Biol. 2002:8:679-93.

159. Jackson ST, Overpeck JT. Responses of plant populations and communities to environmental changes of the late quaternary. Paleobiology. 2000;26:194-220

160. Dawson TP, Jackson ST, House JI, Prentice IC, Mace GM. Beyond predictions: biodiversity conservation in a changing climate. Science. 2011:332:53-8.

161. Huntley B. European post-glacial forests: compositional changes in response to climatic change. J Veg Sci. 1990;1:507-18.

162. Thompson JN. The evolution of species interactions. Science. 1999;284:2116-8.

163. Archer S, Schimel DS, Holland EA. Mechanisms of shrubland expansion: land use, climate or CO2? Clim Change. 1995;29:91-9.

164. Swetnam TW, Allen CD, Betancourt J. Applied Historical Ecology : Using the Past to Manage for the Future Author ( $s$ ): Thomas W. Swetnam, Craig D. Allen and Julio L. Betancourt Published by: Wiley on behalf of the Ecological Society of America Stable URL : http://www.jstor.org/ stable/2. Ecol Appl. 1999:9:1189-206.

165. Jetz W, Wilcove DS, Dobson AP. Projected impacts of climate and landuse change on the global diversity of birds. PLoS Biol. 2007;5:1211-9.

166. Elmberg J, Hessel R, Fox AD, Dalby L. Interpreting seasonal range shifts in migratory birds: a critical assessment of "short-stopping" and a suggested terminology. J Ornithol. 2014;155:571-9. 
167. Honnay O, Verheyen K, Butaye J, Jacquemyn H, Bossuyt B, Hermy M. Possible effects of habitat fragmentation and climate change on the range of forest plant species. Ecol Lett. 2002;5:525-30.

168. Merilä J, Hendry AP. Climate change, adaptation, and phenotypic plasticity: the problem and the evidence. Evol Appl. 2014;7:1-14.

169. Bradshaw $A D, M c n e i l l y ~ T$. Evolutionary response to global climatic change. Ann Bot. 1991;67:5-14.

170. Aitken SN, Yeaman S, Holliday JA, Wang T, Curtis-McLane S. Adaptation, migration or extirpation: climate change outcomes for tree populations. Evol Appl. 2008;1:95-111.

171. Williams BL, Brawn JD, Paige KN. Landscape scale genetic effects of habitat fragmentation on a high gene flow species: Speyeria idalia (Nymphalidae). Mol Ecol. 2003;12:11-20.

172. Young A, Boyle T, Brown T. The population genetic consequences of habitat fragmentation for plants. Trends Ecol Evol. 1996;11:413-8.

173. Menéndez R, Megías AG, Hill JK, Braschler B, Willis SG, Collingham Y, et al. Species richness changes lag behind climate change. Species richness Chang lag behind Clim Chang. York: Royal Society B: Biological Sciences; 2006. p. 1465-70.

174. Thomas JA, Telfer MG, Roy DB, Preston CD, Greenwood JJD, Asher J, et al. Comparative Losses of British Butterflies, Birds, and Plants and the Global Extinction Crisis [Internet]. Sci. Online. Nat. Eur. J. Soil Sci. T. Hallinback, Biol. Conserv. Oikos Biol. Conserv. Environ. Sci. Technol. J. S. Rodwell, Grasslands Mont. Communities Glob. Chang. Biol. 2001. Available from: www.nbu.ac.uk/negtap/.

175. Svenning JC, Skov F. Limited filling of the potential range in European tree species. Ecol Lett. 2004;7:565-73.

176. Jump AS, Peñuelas J. Running to stand still: adaptation and the response of plants to rapid climate change. Ecol Lett. 2005;8:1010-20.

177. Rehfeldt GE, Tchebakova NM, Parfenova YI. Intraspecific responses to climate in Pinus sylvestris. Glob Chang Biol. 2002:8:912-29.

178. LiY, Cohen JM, Rohr JR. Review and synthesis of the effects of climate change on amphibians. Integr Zool. 2013;8:145-61.

179. Huang $X Q$, Börner $A$, Röder MS, Ganal MW. Assessing genetic diversity of wheat (Triticum aestivum L.) germplasm using microsatellite markers. Theor Appl Genet. 2002;105:699-707.

180. Kelly DW, Muirhead JR, Heath DD, Macisaac HJ. Contrasting patterns in genetic diversity following multiple invasions of fresh and brackish waters. Mol Ecol. 2006;15:3641-53.

181. Mitton JB, Duran KL. Genetic variation in piñon pine, Pinus edulis, associated with summer precipitation. Mol Ecol. 2004;13:1259-64.

182. Billington $\mathrm{HL}$, Pelham J. Genetic variation in the date of budburst in Scottish Birch populations: implications for climate change. Funct Ecol. 1991;5:403-9.

183. Savolainen O, Bokma F, García-Gil R, Komulainen P, Repo T. Genetic variation in cessation of growth and frost hardiness and consequences for adaptation of Pinus sy/vestris to climatic changes. For Ecol Manage. 2004;197:79-89.

184. Etterson JR, Shaw RG, Etterson JR, Shaw RG. Constraint to adaptive evolution in response to global warming published by: American Association for the advancement of science linked references are available on JSTOR for this article: evotution in response to global warming. Science. 2001:294:151-4.

185. Potvin C, Tousignant D. Evolutionary consequences of simulated global change: genetic adaptation or adaptive phenotypic plasticity. Oecologia. 1996;108:683-93.

186. Templeton A, Shaw K, Routman E, Davis S. The genetic consequences of habitat fragmentation. Ann Missouri Bot Gard. 1990;77:13-27.

187. Callahan HS, Pigliucci M, Schlichting CD. Developmental phenotypic plasticity: where ecology and evolution meet molecular biology. BioEssays. 1997;19:519-25.

188. Bradshaw AD. Bradshaw. 1ST ed. Caspari EW, Thoday JM, editors. New York: New York: Academic Press; 1965.

189. Sultan SE, et al. Evolutionary implications of phenotypic plasticity in plants. In: Hecht MK, et al., editors. Evol Biol. 1st ed. New York: Plenum Press; 1987. p. 127-78.

190. A.B. Nicotra, O.K. Atkin, S.P. Bonser, A.M. Davidson EJF, U. Mathesius1, P. Poot4, M.D. Purugganan5, C.L. Richards6, F. Valladares7 and M. van Kleunen8. Plant phenotypic plasticity in a changing climate. Trends Plant Sci [Internet]. 2010;15:684-92. Available from: https://pdf.scien cedirectassets.com/271203/1-s2.0-S1360138510X00127/1-s2.0-S1360
138510001986/main.pdf?x-amz-security-token=AgoJb3JpZ2luX2V jEDEaCXVZLWVhc3QtMSJHMEUCIQD65JTEInrk0QpNyDhu5JrtLjaSWd 1sYDLKA3vPEdNArQIgWelwuhLThfyd2mNpok49D6\%2F3c\%2Ff4O 94Hd\%2FeshQ.

191. Toby Kiers E, Palmer TM, Ives AR, Bruno JF, Bronstein JL. Mutualisms in a changing world: an evolutionary perspective. Ecol Lett. 2010;13:1459-74.

192. DeWitt TJ, Sih A, Wilson DS. Costs and limits of phenotypic plasticity. Trends Ecol Evol. 1998;13:77-81.

193. Schlichting CD, Smith H. Phenotypic plasticity linking molecular mechanisms with evolutionary outcomes. Evol Ecol. 2002;16:189-211.

194. Gutschick VP, BassiriRad H. Extreme events as shaping physiology, ecology, and evolution of plants: toward a unified definition and evaluation of their consequences. New Phytol. 2003;160:21-42.

195. Maxwell D, Wiebe K. Land tenure and food security: exploring dynamic linkages. Dev Change. 1999;30:825-49.

196. Pinstrup-Andersen P. Food security: definition and measurement. Food Secur. 2009;1:5-7.

197. Thaman R. Natural resources: biodiversity is the key to food security. Spore. 2005;15:16-16

198. Sathaye J, Shukla PR, Ravindranath NH. Special section: climate change and India climate change, sustainable development and India: global and national concerns. Curr Sci. 2001;90:314-25.

199. Agbogidi OM. Global climate change: a threat to food security and environmental conservation. Br J Environ Clim Chang. 2011;1:74-89.

200. Funk WC, Blouin MS, Corn PS, Maxell BA, Pilliod DS, Amish S, et al. Population structure of Columbia spotted frogs (Rana luteiventris) is strongly affected by the landscape. Mol Ecol. 2005;14:483-96.

201. IPCC. Climate change and biodiversity IPCC Technical Paper V. Rome; 2002.

202. Parry M. The implications of climate change for crop yields, global food supply and risk of hunger. SAT eJournal. 2007;4:1-44.

203. Campbell B, Mann W, Meléndez-Ortiz R, Streck C TT. Agriculture and climate change: a scoping report. Washington Dc; 2011.

204. Schmidhuber J, Tubiello FN. Food security under climate change. Nat Clim Chang. 2016;6:10-3.

205. Edame GE, Anam BE, Fonta WM, Duru E, Edame GE. Int J Humanit Soc Sci. 2011;1:203-17.

206. Juma SG, Kelonye F. Projected rainfall and temperature changes over Bungoma County. Ethiop J Environ Stud Manag. 2016;9:625-40.

207. Cotter J, Tirado R. Food security and climate change: the answer is biodiversity. Amsterdam: Greenpeace Int; 2008.

208. Devereux S. Why does famine persist in Africa? Food Secur. 2009;1:25-35.

209. Lioubimtseva E, Henebry GM. Climate and environmental change in arid Central Asia: Impacts, vulnerability, and adaptations. J Arid Environ. 2009;73:963-77.

210. Bouwer LM. Projections of future extreme weather losses under changes in climate and exposure. Risk Anal. 2013;33:915-30.

211. Magrath J. Climate alarm: disasters increase as climate change bites. Oxfam Policy Pract Clim Chang Resilienc. 2007;3:1-28.

212. Sanchez PA. Linking climate change research with food security and poverty reduction in the tropics. Agric Ecosyst Environ. 2000;82:371-83.

213. Grothmann T, Patt A. Adaptive capacity and human cognition: The process of individual adaptation to climate change. Glob Environ Chang. 2005;15:199-213.

214. Barnett J. Dangerous climate change in the Pacific Islands: food production and food security. Reg Environ Chang. 2011;11:229-37.

215. Redden RJ, Hatfield JL, Lotze-campen H, Hall AE. Crop Adaptation to Climate Change. 1st ed. Yadav SS, Redden RJ, Hatfield JL, Lotze-Campen $H$, Hall AE, Yada M, editors. Chichester: Wiley-Blackwell; 2011.

216. Cowie AL, Penman TD, Gorissen L, Winslow MD, Lehmann J, Tyrrell TD, et al. Towards sustainable land management in the drylands: scientific connections in monitoring and assessing dryland degradation, climate change and biodiversity. L Degrad Dev. 2011;22:248-60.

217. Yadav SS, Redden R, McNeil DL, Patil SA. Climate change and management of cool season grain legume crops. ICRISAT. 2010;4:1-460.

218. Fischer RA, Santiveri F, Vidal IR. Crop rotation, tillage and crop residue management for wheat and maize in the sub-humid tropical highlands I. Wheat and legume performance. F Crop Res. 2002;79:107-22. 
219. Khan ZR, Midega CAO, Pittchar JO, Murage AW, Birkett MA, Bruce TJA, et al. Achieving food security for one million sub-Saharan African poor through push-pull innovation by 2020. Philos Trans R Soc B Biol Sci. 2014;369:1-11.

220. Goudriaan J, Zadoks JC. Global climate change: modelling the potential responses of agro-ecosystems with special reference to crop protection. Environ Pollut. 1995;87:215-24.

221. Tm M, Sesabo J, Ishengoma E, Opile W. Impact of climate change on agricultural production and mitigation. Afr J Hort Sci. 2015;7:27-44.

222. Schmidhube J, Tubiello FN. Food security under climate change. Nat Clim Chang. 2016;6:10-3.

223. Jones K. Zero Hunger, Zero Emissions mitigation, food security, and equity. 2nd ed. Pfeifer K, editor. WASHINGTON, DC: Oxfam; 2AD.

224. Porter JR, Semenov MA. Crop responses to climatic variation. Philos Trans R Soc B Biol Sci. 2005;360:2021-35.

225. Wheeler TR, Craufurd PQ, Ellis RH, Porter JR, Vara Prasad PV. Temperature variability and the yield of annual crops. Agric Ecosyst Environ. 2000;82:159-67.

226. Garcia-Herrera R, Díaz J, Trigo RM, Luterbacher J, Fischer EM. A review of the european summer heat wave of 2003. Crit Rev Environ Sci Technol. 2010;40:267-306.

227. Hatfield JL, Boote KJ, Kimball BA, Ziska LH, Izaurralde RC, Ort D, et al. Climate impacts on agriculture: implications for crop production. Agron J. 2011;103:351-70.

228. Koetse MJ, Rietveld P. The impact of climate change and weather on transport: an overview of empirical findings. Transp Res Part D Transp Environ. 2009;14:205-21. https://doi.org/10.1016/j.trd.2008.12.004.

229. Arndt C, Chinowsky P, Strzepek K, Thurlow J. Climate change and infrastructure investment in developing countries: The case of Mozambique. econstor. 2011. Report No:: 2011/92.

230. Abdulai A, CroleRees A. Determinants of income diversification amongst rural households in Southern Mali. Food Policy. 2001;26:437-52.

231. Fanzo J, Davis C, McLaren R, Choufani J. The effect of climate change across food systems: implications for nutrition outcomes. Glob Food Sec. 2018;18:12-9.

232. Logie A, Hope G. Vulnerability and food insecurity: background concepts for informing the development of a national FIVIMS for South Africa. Encycl Geol. 2005;5:188-94.

233. Sasson A. Food security for Africa: an urgent global challenge. Agric Food Secur. 2012;1:1-16.

234. Ziervogel G, Ericksen PJ. Adapting to climate change to sustain food security. Wiley Interdiscip Rev Clim Chang. 2010;1:525-40.

235. Myers SS, Smith MR, Guth S, Golden CD, Vaitla B, Mueller ND, et al. Climate change and global food systems: potential impacts on food security and undernutrition. Annu Rev Public Health. 2017;38:259-77.

236. Trenberth KE. Changes in precipitation with climate change. Clim Res. 2011;47:123-38.

237. Parry ML, Rosenzweig C, Iglesias A, Livermore M, Fischer G. Effects of climate change on global food production under SRES emissions and socio-economic scenarios. Glob Environ Chang. 2004;14:53-67.

238. Gregory PJ, Ingram JSI, Brklacich M. Climate change and food security. Philos Trans R Soc B Biol Sci. 2005;360:2139-48.

239. Matondi PB, Havnevik K, Beyene A. Biofuels, land grabbing and food security in Africa. 1ST ed. Matondi PB, Havnevik K, Beyene A, editors. New York: FSC; 2011.

240. Rosenzweig C, Iglesias A, Yang XB, Epstein PR, Chivian E. Implications for food production, plant diseases, and pests. Glob Chang Hum Heal. 2001;2:90-104. https://doi.org/10.1023/A:1015086831467.

241. Gleick PH. Water and conflict: fresh water resources and International Security. Int Secur. 1993;18:79-112.

242. Lindenmayer DB, Laurance WF. The ecology, distribution, conservation and management of large old trees. Biol Rev. 2017;92:1434-58.

243. Blench R, Marriage Z. Drought and livestock in semi-arid Africa and southwest Asia [Internet]. Development. London; 1999. Report No.: 117. http://www.odi.org.uk/publications/wp117.pdf.

244. Toulmin C. Access to food, dry season strategies and household size amongst the bambara of central mali. IDS Bull. 2020;51:58-66.

245. Toulmin C. Drought and the farming sector: loss of farm animals and post-drought rehabilitation. Dev Policy Rev. 1987;5:125-48.
246. Coppock DL. The Borana plateau of southern Ethiopia:Synthesis of pastoral research, development, and change. 1st ed. Coppock D., editor. Addis Ababa: aka ILCA and ILRAD; 1994.

247. Morton J, de Haan C. Policy options paper: community based drought management for the pastoral livestock sector in Sub-Saharan Africa. An Alive Policy Note. 2006;5:1-21.

248. Ahmed AGM. Post -Drought Recovery Strategies Horn of Africa : a Review. Soc Sci Res [Internet]. 2002;3:2017. https://www.africaportal. org/publications/post-drought-recovery-strategies-among-the-pasto ral-households-in-the-horn-of-africa-a-review/.

249. Desta S, Coppock DL. Cattle population dynamics in the southern Ethiopian. J Range Manag. 2002;55:439-51.

250. Moorsom, RichardISNI, Franz, Jutta, Mupotola, Moon. Coping with aridity: drought impacts and preparedness in Namibia - experiences from 1992/93. In: Moorsom, RichardISNI, Franz, Jutta, Mupotola, Moon, editors. Coping with Arid drought impacts Prep Namibia - Exp from 1992/93. Frankfurt am Main: Brandes und Apsel; 1995. p. 1_250.

251. Ndikumana L. Financial determinants of domestic investment in sub-Saharan Africa: evidence from the panel data. World Dev. 2000;28:381-400.

252. Roessig JM, Woodley CM, Cech JJ, Hansen LJ. Effects of global climate change on marine and estuarine fishes and fisheries. Rev Fish Biol Fish. 2004;14:251-75.

253. Wysocki LE, Montey K, Popper AN. The influence of ambient temperature and thermal acclimation on hearing in a eurythermal and a stenothermal otophysan fish. J Exp Biol. 2009;212:3091-9.

254. Ficke AD, Myrick CA, Hansen LJ. Potential impacts of global climate change on freshwater fisheries. Rev Fish Biol Fish. 2007;17:581-613.

255. Kaufman J. Co-evolving genes in MHC haplotypes: The "rule" for nonmammalian vertebrates? Immunogenetics. 1999;50:228-36.

256. Tester M, Langridge P. Breeding technologies to increase crop production in a changing world. Science. 2010;327:818-22.

257. Vervoort JM, Thornton PK, Kristjanson P, Förch W, Ericksen PJ, Kok K, et al. Challenges to scenario-guided adaptive action on food security under climate change. Glob Environ Chang. 2014;28:383-94.

258. Pfender WF, Vollmer SS. Freezing temperature effect on survival of Puccinia graminis subsp. graminicola in Festuca arundinacea and Lolium perenne. Plant Dis. 1999;83:1058-62.

259. Zavala JA, Casteel CL, DeLucia EH, Berenbaum MR. Anthropogenic increase in carbon dioxide compromises plant defense against invasive insects. Proc Natl Acad Sci USA. 2008;105:5129-33.

260. Morgounov A, Ablova I, Babayants O, Babayants L, Bespalova L, Khudokormov Z, et al. Genetic protection of wheat from rusts and development of resistant varieties in Russia and Ukraine. Euphytica. 2011;179:297-311.

261. Chakona G, Shackleton CM. Food insecurity in South Africa: to what extent can social grants and consumption of wild foods eradicate hunger? World Dev Perspect. 2019;13:87-94. https://doi.org/10.1016/j. wdp.2019.02.001.

262. Hansen AJ, Neilson RP, Dale VH, Flather CH, Iverson LR, Currie DJ, Shafer $\mathrm{S}$, Cook R, Bartlein PJ. Global change in forests: responses of species, communities, and biomes: interactions between climate change and land use are projected to cause large shifts in biodiversity. Bioscience. 2001;51:765-79.

263. McClean CJ, Doswald N, Küper W, Sommer JH, Barnard P, Lovett JC. Potential impacts of climate change on Sub-Saharan African plant priority area selection. Divers Distrib. 2006;12:645-655l.

264. McClean CJ, Lovett JC, Küper W, Hannah L, Sommer JH, Barthlott W, Termansen M, Smith GF, Tokumine S, Taplin JR. African plant diversity and climate change. Ann Missouri Bot Gard. 2005;92:139-52.

265. Jarvis A, Lane A, Hijmans RJ. The effect of climate change on crop wild relatives. Agric Ecosyst Environ. 2008;126:13-23.

266. Weltzien, E., Rattunde, H.F.W., Clerget, B., Siart, S., Toure, A. and Sagnard F. Sorghum diversity and adaptation to drought in West Africa. Enhancing the use of crop genetic diversity to manage abiotic stress in agricultural production systems. 1st ed. Weltzien, E., Rattunde, H.F.W., Clerget, B., Siart, S., Toure, A. and Sagnard F, editor. Rome: International Plant Genetic Resources Institute; 2006.

267. Matthews RB, Rivington M, Muhammed S, Newton AC, Hallett PD. Adapting crops and cropping systems to future climates to ensure 
food security: The role of crop modelling. Glob Food Sec. 2013;2:248. https://doi.org/10.1016/j.gfs.2012.11.009.

268. Prudhomme R, De PA, Dumas P, Gonzalez R, Leadley P, Levrel H, et al. Combining mitigation strategies to increase co-benefits for biodiversity and food security. Environ Res Lett. 2020;15:1-9.

269. Ainsworth EA, Beier C, Calfapietra C, Ceulemans R, Durand-Tardif M, Farquhar GD, et al. Next generation of elevated [CO2] experiments with crops: a critical investment for feeding the future world. Plant, Cell Environ. 2008;31:1317-24.

270. Fowler C, Mooney PR. Shattering: Food, Politics, and the Loss of Genetic Diversity. 1st ed. Fowler C, Mooney PR, editors. Arizona: Science; 1990.

271. Roman J, Darling JA. Paradox lost : genetic diversity and the success of aquatic invasions. Trends Ecol Evol. 2007;22:465-83.

272. Ye L, Xiong W, Li Z, Yang P, Wu W, Yang G, et al. Climate change impact on China food security in 2050. Agron Sustain Dev. 2013;33:363-74.

273. Foley JA, Ramankutty N, Brauman KA, Cassidy ES, Gerber JS, Johnston M, et al. Solutions for a cultivated planet. Nature. 2011;478:337-42.

274. Tanumihardjo SA, McCulley L, Roh R, Lopez-Ridaura S, Palacios-Rojas N, Gunaratna NS. Maize agro-food systems to ensure food and nutrition security in reference to the Sustainable Development Goals. Glob Food Sec. 2020;25:100327. https://doi.org/10.1016/j.gfs.2019.100327.

275. Hanspach J, Abson DJ, French Collier N, Dorresteijn I, Schultner J, Fischer J. From trade-offs to synergies in food security and biodiversity conservation. Front Ecol Environ. 2017;15:489-94.

276. Tscharntke T, Clough Y, Wanger TC, Jackson L, Motzke I, Perfecto I, et al. Global food security, biodiversity conservation and the future of agricultural intensification. Biol Conserv. 2012;151:53-9.

277. Perrings C, Jackson L, Bawa K, Brussaard L, Brush S, Gavin T, et al. Biodiversity in agricultural landscapes: saving natural capital without losing interest. Conserv Biol. 2006;20:263-4.

278. Godfray HCJ, Crute IR, Haddad L, Muir JF, Nisbett N, Lawrence D, et al. The future of the global food system. Philos Trans R Soc B Biol Sci. 2010;365:2769-77.

279. Besada H, Werner K. An assessment of the effects of Africa's water crisis on food security and management. Int J Water Resour Dev. 2015;31:120-33.

280. Mirza MMQ. Climate change and extreme weather events: Can developing countries adapt? Clim Policy. 2003;3:233-48.

281. Pandey P, Irulappan V, Bagavathiannan MV, Senthil-Kumar M. Impact of combined abiotic and biotic stresses on plant growth and avenues for crop improvement by exploiting physio-morphological traits. Front Plant Sci. 2017:8:1-15.

282. Rosenzweig C, Strzepek KM, Major DC, Iglesias A, Yates DN, McCluskey $A$, et al. Water resources for agriculture in a changing climate: International case studies. Glob Environ Chang. 2004;14:345-60.

283. Godfray HCJ, Beddington JR, Crute IR, Haddad L, Lawrence D, Muir JF, et al. Food security: the challenge of feeding 9 billion people. Science. 2010;327:812-8.

284. Lamarque P, Quétier F, Lavorel S. The diversity of the ecosystem services concept and its implications for their assessment and management. Comptes Rendus - Biol. 2011:334:441-9.

285. Perrings C, Naeem S, Ahrestan F, Bunker DE, Burkill P, Canziani G, et al. Ecosystem Services for 2020. Science. 2010;330:323-4.

286. Perfecto I, Vandermeer J. The agroecological matrix as alternative to the land-sparing/agriculture intensification model. In: Levins R, editor. Proc Natl Acad Sci USA. Michigan: PNAS; 2010. p. 5786-91.

287. Lambin EF, Meyfroidt P. Global land use change, economic globalization, and the looming land scarcity. Proc Natl Acad Sci USA. 2011;108:3465-72.

288. Stevenson JR, Villoria N, Byerlee D, Kelley T, Maredia M. Green Revolution research saved an estimated 18 to 27 million hectares from being brought into agricultural production. Proc Natl Acad Sci USA. 2013;110:8363-8.

289. Cassman KG. Ecological intensification of cereal production systems: yield potential, soil quality, and precision agriculture. Proc Natl Acad Sci USA. 1999;96:5952-9.

290. Montoya D, Gaba S, de Mazancourt C, Bretagnolle V, Loreau M. Reconciling biodiversity conservation, food production and farmers' demand in agricultural landscapes. Ecol Modell. 2020;416:2-21.
291. Fita A, Rodríguez-Burruezo A, Boscaiu M, Prohens J, Vicente O. Breeding and domesticating crops adapted to drought and salinity: a new paradigm for increasing food production. Front Plant Sci. 2015;6:1-14.

292. Lopez-Noriega I, Galluzzi G, Halewood M, Vernooy R, Bertacchini E, Gauchan $\mathrm{D}$, et al. Flows under stress: Availability of plant genetic resources in times of climate and policy change [Internet]. Copenhagen; 2012. Report No.: 18. http://re.indiaenvironmentportal.org.in/files/file/Flows underStress.pdf.

293. Brussaard L, Caron P, Campbell B, Lipper L, Mainka S, Rabbinge R, et al. Reconciling biodiversity conservation and food security: scientific challenges for a new agriculture. Curr Opin Environ Sustain. 2010;2:34-42.

294. Tantawi B. Rice-based production systems for food security and poverty alleviation in the near-east and noth africa: new challenges and technological opportunities. In: Badawi TA, editor.... Glob Mark Sustain Prod Syst ... [Internet]. Rome: FAO; 2004. p. 12-3. Available from: http:// www.fao.org/RICE2004/en/pdf/badawi.pdf.

295. Tuong TP, Bouman BAM. Rice production in water-scarce environments. Water Product. Agric. limits Oppor. Improv. Manila, 2009. Report No.: 4.

296. Power AG. Ecosystem services and agriculture: tradeoffs and synergies. Phil Trans R Soc B. 2010;365:2959-71.

297. Tilman D, Balzer C, Hill J, Befort BL. Global food demand and the sustainable intensification of agriculture. Proc Natl Acad Sci USA. 2011;108:20260-4.

298. Kremen C. Reframing the land-sparing/land-sharing debate for biodiversity conservation. Ann NY Acad Sci. 2015;1355:52-76.

299. Wittman H, Chappell MJ, Abson DJ, Kerr RB, Blesh J, Hanspach J, et al. A social-ecological perspective on harmonizing food security and biodiversity conservation. Reg Environ Chang. 2017;17:1291-301.

300. Macek J, Strejček J, Straka J. Chrysidoidea: Bethylidae (hbitěnkovití). Acta Entomol Musei Natl Pragae. 2007:405:21-40.

301. Noss RF. Assessing and monitoring forest biodiversity: a suggested framework and indicators. For Ecol Manage. 1999;115:135-46.

302. Cotter J, Tirado R. Food Security and Climate Change: The answer is biodiversity. 2008;

303. Padoch C. Saving forests to save biodiversity. Science. 2010;329:1278-80.

304. Seddon N, Chausson A, Berry P, Girardin CAJ, Smith A, Turner B. Understanding the value and limits of nature-based solutions to climate change and other global challenges. Philos Trans R Soc B Biol Sci. 2020;375:1-12.

305. Lipper L, Thornton P, Campbell BM, Baedeker T, Braimoh A, Bwalya $M$, et al. Climate-smart agriculture for food security. Nat Clim Chang. 2014:4:1068-72.

306. Blitzer EJ, Dormann CF, Holzschuh A, Klein AM, Rand TA, Tscharntke T. Spillover of functionally important organisms between managed and natural habitats. Agric Ecosyst Environ. 2012;146:34-43. https://doi.org/ 10.1016/j.agee.2011.09.005.

307. Richmond RH, Rongo T, Golbuu Y, Victor S, Idechong N, Davis G, et al. Watersheds and coral reefs: conservation science, policy, and implementation. Bioscience. 2007:57:598-607.

308. Munang RT, Thiaw I, Rivington M. Ecosystem management: tomorrow's approach to enhancing food security under a changing climate. Sustainability. 2011;2010:937-54.

309. Wollenberg E, Vermeulen SJ, Girvetz E, Loboguerrero AM, Ramirez-Villegas J. Reducing risks to food security from climate change. Glob Food Sec. 2016;11:34-43. https://doi.org/10.1016/j.gfs.2016.06.002.

310. Rice JC, Garcia SM. Fisheries, food security, climate change, and biodiversity: characteristics of the sector and perspectives on emerging issues. ICES J Mar Sci. 2011;68:1343-53.

311. Kraxner F, Nilsson S, Obersteiner M. Negative emissions from BioEnergy use, carbon capture and sequestration (BECS) - The case of biomass production by sustainable forest management from semi-natural temperate forests. Biomass Bioenerg. 2003;24:285-96.

312. Uphoff N. Supporting food security in the 21 st century through resource-conserving increases in agricultural production. Agric Food Secur. 2012;1:1-12.

313. Bele MY, Sonwa DJ, Tiani AM. Adapting the Congo Basin forests management to climate change: linkages among biodiversity, forest loss, and human well-being. For Policy Econ. 2015;50:1-10.

314. Arnold M, Powell B, Shanley P, Sunderland TC. Forests, biodiversity and food security. Int For Rev. 2011;13:259-64. 
315. Ignaciuk A, Vöhringer F, Ruijs A, van lerland EC. Competition between biomass and food production in the presence of energy policies: a partial equilibrium analysis. Energy Policy. 2006;34:1127-38.

316. McKendry P. Energy production from biomass (part 3): Gasification technologies. Bioresour Technol. 2002;83:55-63.

317. Njoroge JM. Climate change-perceived impacts, risks, vulnerability, and response strategies: A case study of Mombasa coastal tourism, Kenya. African J Hosp [Internet]. 2015;4:1_32. Available from: http//:www.ajhtl. comhttp://s1.reutersmedia.net $/$ resources $/ \mathrm{r} / \mathrm{m}=02 \& \mathrm{~d}=2121012 \& \mathrm{t}=$ $2 \& \mathrm{i}=662769753 \& \mathrm{~W}=580 \& \mathrm{fh}=\& \mathrm{fw}=\& \|=\& \mathrm{pl}=\& \mathrm{r}=\mathrm{ALNE} 89 \mathrm{~B} 1 \mathrm{~A}$.

318. Stein BA, Staudt A, Cross MS, Dubois NS, Enquist C, Griffis R, et al. Preparing for and managing change: climate adaptation for biodiversity and ecosystems. Front Ecol Environ. 2013;11:502-10.

319. Wilbanks TJ, Sathaye J. Integrating mitigation and adaptation as responses to climate change: a synthesis. Mitig Adapt Strateg Glob Chang. 2007;12:957-62.

320. Kimmel E. climate change adaptation and Biodiversity. British Columbia; 2009

321. Yagi K, Sriphirom P, Cha-un N, Fusuwankaya K, Chidthaisong A, Damen $B$, et al. Potential and promisingness of technical options for mitigating greenhouse gas emissions from rice cultivation in Southeast Asian countries. Soil Sci Plant Nutr. 2020;66:37-49. https://doi.org/10.1080/ 00380768.2019.1683890.

322. Amundson R, Biardeau L. Correction: Opinion: Soil carbon sequestration is an elusive climate mitigation tool (Proceedings of the National Academy of Sciences of the United States of America (2018) 115 (1165211656) DOI: https://doi.org/10.1073/pnas.1815901115). In: Amundson
R, Biardeau L, editors. Proc Natl Acad Sci U S A. USA: Natl. Acad. Sc; 2019. p. 13143.

323. Kim JA. Regime interplay: the case of biodiversity and climate change. Glob Environ Chang. 2004;14:315-24.

324. Omann I, Stocker A, Jäger J. Climate change as a threat to biodiversity: An application of the DPSIR approach. Ecol Econ. 2009;69:24-31. https://doi.org/10.1016/j.ecolecon.2009.01.003.

325. Pawson SM, Brin A, Brockerhoff EG, Lamb D, Payn TW, Paquette A, et al. Plantation forests, climate change and biodiversity. Biodivers Conserv. 2013;22:1203-27.

326. Haines A, Smith KR, Anderson D, Epstein PR, McMichael AJ, Roberts I, et al. Policies for accelerating access to clean energy, improving health, advancing development, and mitigating climate change. Lancet. 2007;370:1264-81.

327. Mburu SW, Koskey G, Kimiti JM, Ombori O, Maingi JM, Njeru EM. Agrobiodiversity conservation enhances food security in subsistence based farming systems of Eastern Kenya. Agric Food Secur. 2016;5:1-10.

328. Bogdanski A. Integrated food - energy systems for climate-smart agriculture. Agric Food Secur. 2012;1:1-10.

329. Tebkew M, Asfaw Z, Zewudie S. Underutilized wild edible plants in the Chilga District, northwestern Ethiopia : focus on wild woody plants. Agric Syst. 2014;3:1-16.

\section{Publisher's Note}

Springer Nature remains neutral with regard to jurisdictional claims in published maps and institutional affiliations.
Ready to submit your research? Choose BMC and benefit from:

- fast, convenient online submission

- thorough peer review by experienced researchers in your field

- rapid publication on acceptance

- support for research data, including large and complex data types

- gold Open Access which fosters wider collaboration and increased citations

- maximum visibility for your research: over $100 \mathrm{M}$ website views per year

At BMC, research is always in progress.

Learn more biomedcentral.com/submissions 